\title{
Regimes Público e Privado no Setor de Telecomunicações: análise de uma diferença e de uma semelhança
}

Public and Private Regimes in the Telecommunications Sector: A Study on one Difference and one Similarity

Submetido(submitted): 04/12/2014

Parecer(revised): 31/12/2014

Aceito(accepted): 04/01/2015

\author{
Cristiana Leão Quinalia*
}

\section{Resumo}

Propósito - Este artigo tem por objetivo analisar as características dos regimes público e privado estabelecidas na Lei Geral de Telecomunicações (LGT) brasileira, traçando especificidades e conexões entre eles. A categorização dos serviços de telecomunicações e a ampliação do acesso foram eleitas, respectivamente, como possíveis diferença e semelhança entre os regimes.

Metodologia/abordagem/design - Para analisar a diferença entre os regimes presentes na LGT, estudam-se as características de serviço público e as diferentes possibilidades de interpretação de seu enquadramento tanto no regime público como no regime privado, dialogando-se em especial com os art. 21 e 175 da Constituição Federal de 1988 e com a LGT. Por outro lado, estudam-se as políticas de expansão como uma possível semelhança, aprofundando-se as bases legais e mecanismos utilizados nos dois regimes.

Resultados - Adota-se o entendimento de que apenas os serviços de telecomunicações prestados em regime público têm natureza de serviço público. A partir daí, identificam-se elementos de conexão entre os dois regimes, notadamente o fato de ambos serem alvo de ações para ampliação do acesso.

Implicações práticas - $\mathrm{O}$ entendimento de diferença e semelhança entre os regimes permite maior embasamento para proposta de políticas públicas e regulamentações para remodelagem do arcabouço regulatório das telecomunicações no Brasil.

Palavras-chave: regime público, regime privado, serviço público, universalização, massificação.

\section{Abstract}

Purpose - This article aims to analyze the characteristics of public and private regimes established in Brazil's General Telecommunications Law (LGT), outlining specificities and connections between them. The categorization of telecommunications services and universal deployment of services were elected in this study, respectively, as a possible difference and similarity between the regimes.

Methodology/approach/design - So as to analyze differences between public and private regimes described in LGT, this article tackled the building blocks of each regime,

*Graduada em Direito pela Pontifícia Universidade Católica do Rio de Janeiro. Mestre em Direito e Políticas Públicas pelo Centro Universitário de Brasília (UniCEUB). Master em Direito Empresarial pelo Centro Internacional de Formanción Financiera (CIFF), da Universidad de Alcalá, Espanha. Especialista em Regulação da Agência Nacional de Telecomunicações (ANATEL). Email: cris_leao@yahoo.com. 
particularly from the viewpoint of articles 21 and 175 of the Brazilian Constitution of 1988 and the legal framework inaugurated with LGT. To that end this study focused and deepened the legal bases and mechanisms in both public and private regimes.

Findings - In light of this analysis, it is adopted the view that only on the public regime the provision of telecommunications services is considered public service. Still, it is possible to identify elements of connection between the two regimes, notably the fact that both are targeted for policy-oriented expansion.

Practical implications - The understanding of differences and similarities between the regimes provide grounds for improving public policies and regulations.

Keywords: public regime, private regime, public service, universal service, Brazil.

\section{Introdução}

No setor de telecomunicações brasileiro, prevalecia o regime de monopólio por empresas estatais desde a década de 70, sob a holding Telecomunicações Brasileiras S.A. (Telebras). Ocorre que, passadas mais de duas décadas da criação dessa empresa, o acesso às telecomunicações não era democrático, a infraestrutura estava concentrada em determinadas áreas e exigia-se mudança (SIQUEIRA, 1993; COSTA, 1996).

Ciente da necessidade de avanços, Fernando Henrique Cardoso elaborou capítulo referente às telecomunicações, em proposta ao governo. Nele, salientava a importância de investir em infraestrutura como uma ação fundamental para o crescimento econômico e social (CARDOSO, 2008, p. 23). Quando Chefe do Executivo, no segundo semestre de 1995, por meio do Ministério das Comunicações, lançou o Programa de Recuperação e Ampliação do Sistema de Telecomunicações e do Sistema Postal (Paste).

Em paralelo às discussões sobre a deficiência do setor, na década de 90 , questionava-se o papel do Estado. O Plano Diretor de Reforma do Aparelho do Estado (MARE, 1995, p. 6) identificou a crise no modelo burocrático e desvio das atribuições do Estado e sugeriu reforma estatal para reforçar as funções estatais de regulação e coordenação (art. 174 da Constituição Federal de 1988). A Administração “deve ser permeável à maior participação dos agentes privados e/ou das organizações da sociedade civil e deslocar a ênfase dos procedimentos (meios) para os resultados (fins)" (MARE, 1995, p. 16).

Considerando a tendência de organização e atuação do Estado do final do século passado, Almiro do Couto e Silva reconhece uma tendência de recuo do Estado e ampliação das atividades do setor privado, e prevê novas parceiras e formas de colaboração entre os setores público e privados: "por meios de direito público ou de direito privado, haverão certamente de desafiar ainda mais agudamente a imaginação dos juristas no milénio que se aproxima." (SILVA, 2003, p. 208). 
Considerando, ainda, a tendência de organização e atuação do Estado do final do século passado, para Maria João Estorninho, o setor de telecomunicações é um exemplo típico desse momento de transformação (MOTTA, 2006). Para ela, as privatizações promovidas pelas Administrações Públicas, em sua maioria, nos anos 80 e 90 do século passado, são exemplo de interseção entre regime público e privado, justamente por acentuar a tendência "às formas jurídico-privadas de organização e de actuação administrativas" (ESTORNINHO, 1996, p. 47).

Nesse contexto, foi promulgada a Emenda Constitucional $\mathrm{n}^{\circ} 8$, de 25 de agosto de 1995, que alterou os incisos XI e XII, "a" do art. 21 da Constituição Federal de 1988. Por ordem constitucional, aprovou-se a Lei no 9.472, de 16 de julho de 1997 (LGT). A Lei Geral das Telecomunicações (LGT) determinou a criação da Agência Nacional das Telecomunicações (ANATEL), estabeleceu critérios para a desestatização ${ }^{1}$ do Sistema Telebras e desenhou o ambiente pósprivatização para as outorgas de concessões, permissões e autorizações.

A LGT estabeleceu dois regimes jurídicos pelos quais os serviços de telecomunicações seriam prestados: o regime público e o regime privado.

Entende-se por serviço de telecomunicações em regime público aquele que a União compromete-se a assegurar, prestado mediante concessão ou permissão, na modalidade de serviços de interesse coletivo, com atribuição (à prestadora) de obrigações de universalização e de continuidade (art. 63, parágrafo único; e, art. 64, caput, da LGT). Entende-se por serviço de telecomunicações em regime privado, o prestado mediante autorização, na modalidade de serviços de interesse coletivo ou restrito, ${ }^{2}$ apoiado nos princípios constitucionais da atividade econômica e que, excepcionalmente, tem outorga condicionada (arts. 63, 64, 67, 126, 131, 136 da LGT).

Note-se que a LGT estabeleceu características distintivas para os regimes. Contudo, essas, em alguma medida, interceptam-se e merecem

${ }^{1}$ As questões são retratadas por DERANI (2002, p. 115). "As questões da privatização, dos serviços públicos e da concorrência situam-se no entroncamento da economia com o direito e a política. A exploração de um serviço público substitui, a princípio, a concorrência, porque sua produção é uma necessidade social e, portanto, independe dos estímulos produzidos pelo mercado."

${ }^{2} \mathrm{O}$ art. 17, da Resolução n ${ }^{\circ}$ 73/1998, da ANATEL, definiu interesse coletivo como "aquele cuja prestação deve ser proporcionada pela prestadora a qualquer interessado na sua fruição, em condições não discriminatórias, observados os requisitos da regulamentação." Enquanto os serviços de interesse coletivo são prestados a todos os interessados em condições não discriminatórias, os de interesse restrito (art. 18, da citada Resolução) são destinados ao uso próprio ou a determinados grupos de usuários. Os serviços prestados em interesse coletivo devem cumprir o que a LGT chama de "função social do serviço de interesse coletivo" (art. 127, VIII, da LGT). O Ato $n^{\circ} 3.833$, de 20 de junho de 2013, categoriza os serviços e suas possibilidades de abrangência. 
aprofundamento. O objetivo desse artigo é analisar os regimes público e privado estabelecidos na Lei Geral de Telecomunicações (LGT) a partir de uma possível diferença e uma possível semelhança como âncoras conceituais de comparação.

A diferença seria a categorização dos serviços prestados em telecomunicações como serviços públicos, considerando as três possibilidades de outorgas: concessão, permissão e autorização. A semelhança seria a ampliação do acesso aos serviços por meio de universalização e massificação, considerando a obrigação de universalização no regime público e a necessidade de observância dos princípios da atividade econômica, ainda que se permitam condicionantes à expedição de autorização no regime privado.

\section{Serviços de Telecomunicações}

A noção de serviço público nasce na França. Leon Duguit ${ }^{3}$, Maurice Hauriou $^{4}$ e Gaston Jèze são considerados os principais expoentes dessa discussão.

Para o estudo do tema, cabe destacar alguns ensinamentos de Jèze. Segundo o autor, o serviço público está sob a égide de um regime especial e regras especiais, normas, com fulcro em facilitar a satisfação do interesse geral. Ele ressalta, porém, que o serviço público não é a única forma de atingir o interesse público. ${ }^{5}$ Além disso, assim como para Duguit, a identificação de um serviço como público e suas regras são suscetíveis a modificações (JÈZE, 1928, p. 284-285); variam no tempo, uma vez que os interesses gerais variam de acordo com a vontade dos governantes (JÈZE, 1928, p. 290).

O serviço público se caracteriza com sua criação por lei, que poderá fazêla de forma expressa ou de forma genérica (JÈZE, 1928, p. 105-107). Como nem sempre a criação de um serviço público é de simples identificação, não haveria um critério único para reconhecer a vontade do governante, mas um conjunto de

${ }^{3}$ Para DUGUIT (2005, p. 65), serviço público é “(...) toda actividad cuyo cumplimiento debe ser regulado, asegurado y controlado por los gobernantes, porque el cumplimiento de esta actividad es indispensable para la realización y el desenvolvimiento de la interdependencia social, y porque, además, es de tal naturaleza que no puede ser completamente asegurada sino mediante la intervención de la fuerza gobernante."

${ }^{4}$ Para CAETANO (1996, p. 217), "foi, sobretudo, Hauriou quem, na escola francesa do começo do presente século, pôs em relevo a importância do serviço público como 'serviço técnico prestado ao público de maneira regular e contínua para satisfazer a ordem pública e por uma organização pública.' (Précis de Droit Administratif, $10^{\mathrm{a}}$ ed., 1921, p. 25)".

${ }^{5}$ Para Jèze (1928, p. 289), "En resumen el servicio público es un procedimiento - y no el único - con que se da satisfacción a necesidad de interese general. Decir que en todo caso existe servicio público significa que han de aplicarse reglas y teorías especiales, que existe un régimen jurídico especial, régimen de índole legal y reglamentaria". 
circunstâncias, tais como: regras especiais para assegurar funcionamento e organização; existência de monopólio; atos de gestão; controle do tribunal de contas; autoridade pública que estabeleça determinado serviço como público (JÈZE, 1928, p. 291-293). Para o autor, identificado um serviço público, o regime aplicado é o público.

Atualmente, direito administrativo e serviços públicos não se confundem. Contudo, as posições e contribuições dos citados autores continuam norteando as discussões. Independentemente das propostas apresentadas, a premissa de que os serviços públicos variam no tempo e no espaço é válida e irrefutável. É possível que essa característica seja um fator desfavorável a uma definição uníssona.

A doutrina, normalmente, classifica a expressão "serviço público" em sentido amplo e em sentido estrito. ${ }^{6}$ No direito pátrio, a Constituição Federal de 1988 utiliza a expressão "serviços públicos" em ambos os sentidos (art. 40, § 16; art 21, XIV; e, art. 175). "Uma das tarefas mais complicadas para a doutrina é identificar quando a Constituição faz uso da expressão em um sentido ou em outro.” (AGUILLAR, 2011, p. 26). Na prática, essa diferenciação dependerá de análise casuística e do conceito de serviço público adotado. Entende-se por serviço público, em sentido estrito, aquelas atividades desempenhadas sob a égide do art. 175 da Constituição Federal de 1988 e que são passíveis de delegação. E é essa noção de serviço público que interessa a esse trabalho.

Para auxiliar a identificação dos serviços públicos em sentido estrito, a doutrina, tradicionalmente reconhece três critérios ou elementos: subjetivo, formal e material. ${ }^{7}$ Considerando os três elementos, percebe-se que os autores propõem definições que focalizam, em graus variados, cada um deles (CAVALCANTI, 1967, p. 204; LIMA, 1982, p. 82-83; CAETANO, 1996, p. 216; MEDAUAR, 2007, p. 314-315). Em geral, nenhum é ignorado, muito embora não sejam imprescindíveis (DI PIETRO, 2012, p. 105). De fato, para o setor de telecomunicações, dos três elementos apresentados, o terceiro, se

${ }^{6}$ Para DI PIETRO (2012, p. 103), o serviço público em sentido amplo englobaria todas as funções e atividades desenvolvidas pelo Estado, ou seja, a concepção de Duguit. Já o serviço público em sentido estrito seria o serviço público propriamente dito.

${ }^{7} \mathrm{O}$ elemento subjetivo reconhece que a criação do serviço público depende de lei e será gerido direta ou indiretamente pelo Estado. O elemento formal relaciona-se ao regime jurídico ao qual o serviço público é prestado, é dizer, identifica-o total ou em partes ao direito público. Por fim, o elemento material refere-se à premissa de que o serviço público deve ter um caráter essencial. Ressalta-se o entendimento de que essa afirmação não deve gerar uma conclusão de que as necessidades sociais serão sempre satisfeitas por meio de serviços públicos, como já ensinara Jèze. Para aprofundamento do tema, vide MELLO (1968, p. 151-158). 
percebido isoladamente, não permitirá uma identificação correta de serviços públicos.

Norteados pelos estudos doutrinários e, em especial, pelo descrito na Constituição Federal de 1988, entende-se que o mais eficaz não seria se concentrar na definição de serviço público, mas em suas características. Assim sendo, a fim de identificar se a atividade é serviço público em sentido estrito, propõe-se verificar se:

a) o Estado é o titular do serviço, se por meio de normas, direta ou indiretamente, opta-se por assegurar a existência de serviço essencial;

b) o serviço pode ser prestado diretamente ou se é passível de delegação. De acordo com o art. 175 da Constituição Federal de 1988, apenas concessão e permissão são as formas de delegação de serviço público;

c) exige-se a satisfação dos princípios do serviço público, além de regras específicas, pelas quais se verifica casuisticamente a ingerência do Estado; ${ }^{8}$ e,

d) a remuneração do serviço é obtida mediante pagamento (tarifas ou taxas) do usuário que teve o serviço prestado, salvo exceções legais. ${ }^{9}$

Verificadas essas características, estar-se-á diante de um serviço público que demandará tratamento de regime público. A confirmação ou ausência de um dos itens não necessariamente indica a existência de serviço público. Ou seja, os itens devem ser verificados cumulativamente.

Embora a Constituição Federal de 1988 permita que os serviços de telecomunicações (art. 21, XI) sejam explorados diretamente, a LGT atém-se somente à exploração pela iniciativa privada. Isso significa que, ao estipular a divisão entre regime público e regime privado, a LGT estabelece regras com graus de exigência distintos para a iniciativa privada. Nesse sentido, aprofundase a análise das quatro características para a identificação de um serviço público, nos dois regimes da LGT, na seguinte ordem e títulos: remunerações; princípios; outorgas de serviços; e titularidades.

A conclusão alcançada é a de que os serviços prestados em regime público enquadram-se na classificação de serviço público, enquanto aqueles

\footnotetext{
${ }^{8} \mathrm{~A}$ hipótese de bens reversíveis e auditorias dos tribunais de contas são exemplos dessa situação.

${ }^{9}$ Não sendo a tarifa suficiente para adequar a remuneração do concessionário à modicidade que deve permear a sua fixação, a Lei $n^{\circ} 8.987 / 1995$ prevê outras formas, alternativas, de remuneração do concessionário de serviços públicos (B ATISTA, 2005, p. 116). Acredita-se também na possibilidade de um serviço público específico sofrer forma distinta de remuneração em virtude de lei que assim discipline.
} 
prestados em regime privado não. Todavia, reconhece-se não haver consenso sobre o tema, como se verá a seguir.

\section{Remunerações}

No serviço público, a remuneração é obtida mediante pagamento (tarifas ou taxas $)^{10}$ do usuário que teve o serviço prestado, salvo exceções legais.

Cabe, ainda, citar a Súmula 545, do Supremo Tribunal Federal: "preços de serviços públicos e taxas não se confundem, porque estas, diferentemente daqueles, são compulsórias e tem sua cobrança condicionada a prévia autorização orçamentária, em relação a lei que as instituiu."

Dessas duas formas de pagamento, interessa a remuneração tarifária e sua função, segundo Joana Paula Batista:

“(...) em jogo a concessão do serviço público, nasce o poder tarifário da Administração, que the possibilita fixar tarifas, segundo os termos estabelecidos na proposta da licitação da concessão do serviço, garantindo-se ao concessionário o equilíbrio inicialmente contratado com 0 poder concedente." (BATISTA, 2005, p. 72)

A remuneração das concessionárias e permissionárias do setor de telecomunicações, regime público, ocorre por meio de tarifas pagas pelos usuários que usufruem do serviço (respectivamente, art. 93, VII e 120, III da LGT). Cabe à Anatel controlar, acompanhar e revisar as tarifas dos serviços prestados no regime público, bem como homologar reajustes (art. 19, VII, art. 86, parágrafo único, I da LGT). Admite-se que as concessionárias possuam fontes alternativas de receitas (art. 83 da LGT).

Por outro lado, os serviços de telecomunicações prestados em regime privado são remunerados por preço. O art. 129 da LGT determina que o preço é livre, salvo abusos econômicos e estipulações regulamentares. Isso significa que o preço cobrado pelas autorizadas forma-se atendendo à realidade do mercado, influenciado pela oferta e demanda; porém, sob a regulamentação e fiscalização da ANATEL, quando necessárias. É evidente que toda regulamentação gera custos às empresas e isso causa impacto no preço final do serviço prestado. Citase, como exemplo, o fato de a ANATEL estabelecer os critérios para fixação dos valores devidos a título de remuneração pelo uso de redes do Serviço Móvel Pessoal (SMP), bem como procedimentos para cobrança e repasse desses

${ }^{10}$ Para MACHADO (2005, p. 291), “[A]s tarifas são a remuneração paga pelos usuários de serviços públicos prestados por empresas privadas que agem na condição de delegadas do Poder Público." Já as taxas são recebidas quando o serviço é prestado pelo próprio Poder Público. 
valores entre as operadoras. Cabe à ANATEL analisar os impactos de cada regulamentação.

Fato é que a regra do "preço livre" opõe-se àquela estabelecida no regime público de telecomunicações, que indica que a remuneração dar-se-á por tarifa (WALD et al., 2004, p. 174-178).

\section{Princípios}

Os princípios do serviço público auxiliam a individualizá-lo das demais atividades prestadas pela Administração ou pela iniciativa privada. Servem, ainda, como pontos comuns entre os diferentes serviços públicos (DROMI, 1996, p. 532). Além disso, determinam obrigações e direitos dos usuários, pelos quais se verifica, casuisticamente, a ingerência do Estado.

Louis Rolland, integrante da Escola de Bordeaux, indica os seguintes princípios dos serviços públicos: vínculo estatal da atividade que deve promover o bem comum; a continuidade do serviço prestado; a adaptabilidade e modificação de sua organização; e, a igualdade entre os usuários (ROLLAND, 1947, p. 18).

A Lei das Concessões enumera os princípios norteadores dos serviços públicos em seu art. $6^{\circ}, \S 1^{\circ}$, ao indicar que a prestação adequada deve satisfazer "as condições de regularidade, continuidade, eficiência, segurança, atualidade, generalidade, cortesia na sua prestação e modicidade das tarifas." Mesmo não tendo o caráter de lei geral, entende-se, que, na execução dos serviços públicos, todos os princípios acima enumerados devem ser cumpridos. Reconhece-se, porém, que normas setoriais determinem o grau de importância desses princípios e a eventual necessidade de cumprimento de outros.

De acordo com a LGT, os serviços prestados em regime público devem cumprir, em especial, os princípios da continuidade e universalização (art. 64 da LGT). A universalização será discutida adiante, em comparação com o conceito de massificação (art. 79, § $1^{\circ}$ da LGT).

A LGT define, como continuidade, as obrigações que permitam aos usuários dos serviços sua fruição de forma ininterrupta, sem paralisações injustificadas, devendo os serviços estar à disposição e em condições adequadas de uso (art. 79, § $2^{\circ}$ da LGT). Essa orientação vale para as concessionárias e para a União.

Considerando que a União obriga-se, legalmente, no âmbito do regime público, a continuar prestando o serviço, isso significa que o Estado deve garantir sua existência, ou seja, ele é o titular dos serviços prestados nesse regime. Posto de outra forma: "Se o serviço público é atividade de titularidade do Estado e o Estado é um ente voltado à permanência, igualmente contínuas devem ser suas tarefas" (HORBACH, 2013, p. 555). 
E é sob essa perspectiva que as concessões têm regras mais rígidas e exigem maior controle na gestão de suas atividades. Cita-se, como exemplo, a preocupação da LGT em estabelecer regras mínimas para intervenção, que poderá ser decretada por ato da ANATEL, critérios que a precedem e as condições (arts. 110 e 111 da LGT). Foi estabelecido que, em havendo a extinção da concessão (art. 102 e seguintes da LGT), transmitir-se-á a posse dos bens reversíveis à União. ${ }^{11}$

Os demais princípios dos serviços públicos igualmente se aplicam à concessão. Cita-se, como exemplo, o princípio da atualidade. A indenização de bem a ser revertido à União, ao final da concessão, só ocorrerá para os investimentos não amortizados e "que tenham sido realizados com o objetivo de garantir a continuidade e atualidade do serviço concedido." (art. 102, parágrafo único da LGT).

No contrato de concessão do Serviço Telefônico Fixo Comutado (STFC), seu conceito é detalhado, sendo utilizado, por vezes, como sinônimo de modernização de equipamentos, de instalações e de técnicas de prestação de serviços que, por sua vez, é pressuposto básico da concessão (Anexo I à Resolução ANATEL 552, de 10 de dezembro de 2010, capítulo V e cláusula 6.1, $\left.\S 4^{\circ}\right)$.

Nesse contexto, chama-se atenção ao caput da cláusula 6.1 do contrato de concessão/2010. Ela determina o cumprimento dos demais princípios dos serviços públicos mencionados na Lei de Concessões. Embora o art. 210 da LGT exclua a aplicação da Lei de Concessões, não se verifica óbice em utilizála como referência.

Por outro lado, sem que se perca a potestade de regular, o art. 126 da LGT determina que os serviços de telecomunicações prestados em regime privado são apoiados nos princípios constitucionais da atividade econômica. $\mathrm{Ou}$ seja, são resguardados os imperativos da livre iniciativa, a fim de estimular e fomentar a participação do mercado (CASSAGNE, 1994, p. 90). Há uma tendência mundial, não tão recente, de estimular a livre concorrência de serviços inicialmente definidos como públicos. ${ }^{12}$

${ }^{11}$ Para ESCOBAR (2005), "Reversão é a passagem ao poder concedente dos bens do concessionário, necessários ao exercício do serviço público, uma vez extinta a concessão. (...) Essa reversão abrange os bens de qualquer natureza, vinculados à prestação do serviço que a concessionária deve entregar."

${ }^{12}$ Sobre o tema PARADA et al. (2006, p. 927): "Es indudable la progenie americana de esa ideología de libre mercado en el marco de una liberalización económica. Esta no supone falta de regulación ni de intervención, sino una nueva orientación de la regulación y de la intervención tendentes a garantizar que el mercado por sí mismo garantice a mejores precios y calidades los bienes y servicios que con anterioridad el 
Em síntese, enquanto no regime privado a regra é seguir os princípios da atividade econômica, no regime público, exige-se a satisfação dos princípios do serviço público.

\section{Outorgas de serviços}

A ausência de definição unânime de serviço público não impede que o Estado delegue atividades de sua titularidade. A possibilidade de delegar é uma das características do serviço público. ${ }^{13}$ De acordo com o art. 175 da Constituição Federal de 1988, a prestação de serviço público pode ser delegada por meio de concessão ou permissão.

A opção por delegar é, antes de tudo, um ato do poder público. Por meio de licitação, é escolhida a proposta mais vantajosa ao interesse público, observados os princípios constitucionais e a legislação específica. O parágrafo único do art. 175 da Constituição Federal de 1988 determina que lei disponha sobre política tarifária, contratos, manutenção, extinção, condições de fiscalização e direitos dos usuários na prestação do serviço.

Depois de vários projetos - inclusive anteriores à Constituição Federal de 1988 (WALD et al., 2004, p. 146) - recebidos no Congresso para regulamentar as concessões, a Lei $n^{\circ}$ 8.987, de 13 de fevereiro de 1995, veio cumprir essa determinação constitucional. A Lei "contribui para a fixação do perfil da concessão (...)" (CARVALHO FILHO, 2013, p. 371), contudo, não impede inovações legislativas que não sejam de competência própria da Lei de Concessões ou que considerem especificidades do setor (MOREIRA NETO, 2003, p. 423). Na mesma linha, Vera Monteiro indica que a simples leitura da Constituição Federal de 1988 ou da Lei no 8.987/1995 "não esclarece, tampouco dita o regime da permissão de serviço público no Direito Brasileiro" (MONTEIRO, 2010, p. 82).

É necessária, portanto, a análise do tema a partir das leis setoriais que possam endereçar situações específicas. É o caso da LGT que, em seu art. 210, exclui para a outorga de serviços de telecomunicações a aplicação da Lei de Concessões, assim como da Lei de Licitações n ${ }^{\circ}$ 8.666/1993.

O parágrafo único do art. 63 determina que o serviço de telecomunicações, em regime público, é o prestado mediante concessão ou

Estado aseguraba directamente o a través de sus empresas públicas o concesionarios monopólicos."

${ }^{13}$ Para Aguillar $(2011,53)$, a partir da CF/88, em especial do art. 175, no Brasil, deixam de existir serviços públicos indelegáveis. Para ele, as atividades indelegáveis classificamse como funções públicas. 
permissão. Já no âmbito do regime privado, os serviços são prestados mediante outorga de autorização.

Passa-se à análise das características e especificidades das concessões, permissões e autorizações no âmbito do setor de telecomunicações. O objetivo é demonstrar como as duas primeiras possuem critérios bem delimitados em lei, demonstrando serem delegações de serviços públicos.

\section{Concessão}

A LGT determina, como forma de seleção da concessionária, a licitação (arts. 88, 91 e 92 da LGT). Indica, ainda, que as outorgas dos serviços de telefonia fixa, originadas da privatização do sistema Telebras, sejam concessões (arts. 190, 193 e 198, da LGT; e, Decreto n 2.534/1998).

O contrato de concessão é o vínculo jurídico e desempenha função reguladora, publicado resumidamente no Diário Oficial da União como condição de sua eficácia (art. 93, parágrafo único). Dentre outras regras, nele está estabelecido o prazo da concessão. De acordo com o art. 99 da LGT, as concessões terão prazo máximo de vinte anos, podendo ser prorrogadas, uma única vez, por igual período, desde que cumpridos requisitos legais. Ocorre que, quando das primeiras concessões, optou-se por estabelecer um prazo menor, até 2005. Já na prorrogação realizada, utilizou-se o prazo máximo de vinte anos, até 2025, com revisão quinquenal. As revisões servem para estabelecer novas metas as outorgas.

Embora o desempenho do serviço pela concessionária corra por sua conta e risco (art. 83, parágrafo único, da LGT), Paulo Roberto Ferreira Motta, acredita haver mitigação desses riscos. Ele justifica que, por ser o dinheiro do Fundo de Universalização dos Serviços de Telecomunicações (FUST) composto, em sua maioria, por contas telefônicas pagas pelos usuários, há evidente socialização do dever de universalização, risco financeiro que deveria ser assumido apenas pelo concessionário. ${ }^{14}$ Apesar de se discordar da crítica ao sistema de universalização, a afirmação é pertinente por identificar uma mitigação dos riscos.

Por fim, a concessão extinguir-se-á por advento do termo contratual, encampação, caducidade, rescisão e anulação, conforme determina o art. 112 da LGT. Extinta a concessão, a União passa a ser detentora dos direitos e dos

${ }^{14}$ Segundo MOTTA (2006, p. 678), "Pode-se concluir que as concessões, ao menos neste modelo, não são atividades exercidas por conta e risco do concessionário, uma vez que os custos e os riscos presentes no atendimento às localidades com menos de 100 habitantes (...) ou a instituições de ensino, bibliotecas (...) são suportadas parcialmente pelos usuários." 
deveres relativos à prestação do serviço (arts. 112, parágrafo único; e, art. 102 da LGT). Nessa oportunidade, realiza-se o ajuste de contas, os bens necessários para a manutenção do serviço voltam a União, que deve reembolsar os investimentos não amortizados.

\section{Permissão}

No setor de telecomunicações, a permissão (art. 118 da LGT) tem caráter emergencial e transitório, é dizer, quando situação excepcional comprometa o funcionamento do serviço e que, por peculiaridades, não possa ser atendida, de forma conveniente ou em prazo adequado, pela concessionária ou nova concessão. Trata-se de faculdade da União, com base no princípio da continuidade, manter serviços prestados em regime público, sem que seja necessária sua gestão direta.

Nesse contexto, o art. 119 da LGT determina a realização de procedimento licitatório simplificado pela ANATEL. Ocorre que a ADI 1.6685/DF, de 1998, ajuizada junto ao Supremo Tribunal Federal, questionou, entre outros, esse procedimento. Por votação unânime, o STF deferiu pedido de medida cautelar para suspender as expressões "simplificado" e "nos termos por ela regulados" constantes no artigo.

A hipótese de permissão já seria per si extrema e remota. Ocorre que, com a decisão do Supremo, o instituto parece ter perdido função, uma vez que se devem seguir os trâmites de uma concessão. Ainda, a ausência de celeridade do procedimento não gera vantagens em licitar uma permissão.

A outorga de permissão, caso venha a existir, será a título precário e pode-se revogar a permissão antes do prazo estipulado no contrato, baseando-se em razões de conveniência e oportunidade relevantes e supervenientes à outorga, sem direito a indenização (art. 123). Por outro lado, a permissão pode ser mantida, mesmo vencido seu prazo máximo, se persistir a situação excepcional que a motivou (art. 124).

\section{Autorização}

A doutrina tradicional (MEIRELLES, 2004, p. 385) entende que a autorização é ato discricionário, dada a título precário e dispensa o procedimento licitatório, desde que garantidas isonomia e impessoalidade. Contudo, essas particularidades não são aderentes a todas as autorizações. Em verdade, o vocábulo autorização não tem sentido unívoco na Constituição (CRETELLA, 1980, p. 372 e 378; DI PIETRO, 2012, p. 233-234), e, portanto, para as autorizações mencionadas no art. 21, XI e XII da Constituição Federal de 1988 e nas leis deles decorrentes, é imperioso questionar tais características. 
Acredita-se que o sentido da autorização constitucional do art. 21 segue a orientação ensinada por Guimarães Menegale. Para ele, a autorização é "remoção de óbice jurídico e a restauração da liberdade material do indivíduo, cujo, exercício, em cada caso, a norma legal adstrinja" (MENEGALE, 1957, p. 55-56). Acrescente-se o entendimento de que, a partir da Constituição Federal de 1988, a restauração abrange também a liberdade empresarial e livre iniciativa.

A autorização de serviços de telecomunicações ${ }^{15}$ não é precária; não tem vigência sujeita ao termo final; extingue-se somente por cassação, caducidade, decaimento, renúncia ou anulação (art. 138 da LGT). Floriano de Azevedo Marques Neto, após analisar o marco normativo das telecomunicações, verifica "que nada há em lei ou na Constituição que determine ser a autorização necessariamente precária e vulnerável” (MARQUES NETO, 2003, p. 345). Carlos Ari Sundfeld, referindo-se à lei de petróleo, acrescenta que, igualmente no Direito Comparado, não se encontra vinculação estrita entre autorização e precariedade e que, ao contrário, "registra um histórico multifacético em torno dessa expressão. (...) Em suma, a autorização terá ou não a nota de precariedade segundo o que houver disposto a lei. Doutrina não é lei, como se sabe" (SUNDFELD, 2006, p. 394).

A autorização de serviços da LGT não é ato discricionário; é um ato vinculado quando preenchidas as condições objetivas (art. 132 da LGT) e subjetivas (arts. 133 e 134 da LGT) necessárias. Em relação ao tema, cita-se Andreas J. Krell para quem a variação entre ato discricionário ou vinculativo é uma questão gradual, depende da liberdade concedida pelo legislador (KRELL, 2004, p. 184-185). Na mesma linha, Santi Romano afirma que o ato de autorização pode ser mais ou menos discricionário: "Dizemos mais ou menos discricionário porque há casos em que, quando ocorrem certas condições determinadas pela lei, a Administração deve autorizar". ${ }^{16}$ Guimarães Menegale, fiel a sua noção de autorização, afirma que, verificados os requisitos normativos, a autoridade deve deferir autorização, a fim de efetivar o direito que, em potencial, já assistia ao pleiteante que se torna credor. A autorização, portanto, "não se insere na categoria dos atos discricionários; aliás, contraria a natureza da

${ }^{15}$ A LGT trata também da autorização de direito de uso de radiofrequência que sempre estará associada a outorga de serviço. Portanto, não é uma autorização de serviço. Por ser bem público da União, ela terá tempo determinado, não ultrapassados 20 (vinte) anos, podendo seu prazo ser prorrogado por igual período uma única vez (art. 167 da LGT). Por estar associada a um serviço, na hipótese desse serviço ser extinto, também se extinguirá a outorga de radiofrequência. Contudo, nada impede que se obtenham novas outorgas tanto do serviço quanto da radiofrequência (art. 163 da LGT).

${ }^{16}$ Conforme ROMANO (1937, p. 241), "Diciamo più o meno discrezionale, perchè ci sono dei casi in cui, quando ricorrono certe condizioni determinate dalla legge, l'amministrazione deve autorizzare." 
autorização, quando supõe a ocorrência prévia do direito, cujo exercitamento não faz senão desembaraçar" (MENEGALE, 1957, p. 57-58). Em síntese:

"Regra geral, a autorização é um ato administrativo de estrutura declaratória - constata e declara a verificação dos pressupostos de fato e de direito préestabelecidos em lei formal estrita (arts. 132 e 133 da LGT); e tem sempre efeito constitutivo - a declaração verificada constitui um efeito de certeza quanto ao enquadramento da situação de interesse no quadro de que a lei faz depender o exercício do direito de que é titular.

Este duplo caráter submete 0 ato de autorização para prestação de serviços de telecomunicações ao regime dos atos vinculados e constitutivos de direitos: vinculado, porque na sua prática a ANATEL não tem liberdade de decisão (art. 131, § $1^{\circ}$, da LGT); e constitutivo de direitos porque não é suscetível de revogação pela ANATEL com fundamento em conveniência e oportunidade (art. 138 da LGT)." (XAVIER, 2003, p. 39)

Considerando os altos custos de investimento, o mercado não suportaria a instabilidade de uma autorização de serviços de telecomunicações precária ou discricionária, sob a pena de desestímulo a prestação dos serviços.

Não há prazo ou limite ao número de autorizações de serviço ou prazo para prestação (arts. 136 e 138 da LGT), salvo em caso de impossibilidade técnica ou quando o excesso de competidores comprometer a prestação de um serviço de interesse coletivo. Nessas exceções, há processo licitatório com prazo de outorga estabelecido. Por fim, destaca-se que, nas autorizações, a publicação do ato de autorização, no Diário Oficila da União (D.O.U.), é o instrumento que passa a obrigar o outorgado (art. $131, \S 4^{\circ}$ da LGT).

\section{Titularidades}

$\mathrm{O}$ art. 175 da Constituição Federal de 1988 incumbe o poder público de assegurar a prestação de alguns serviços essenciais diretamente ou por delegação. Como o artigo não os enumera, e considerando o elemento subjetivo dos serviços públicos, entende-se que base legal, ainda que infraconstitucional, pode definir a obrigação de um ente federativo assegurar a prestação de serviço considerado essencial (SUNDFELD, 2006b, p. 318; GROTTI, 2006, p. 65; MEDAUAR, 2007, p. 314-315; DI PIETRO, 2012, p. 105).

Todo serviço público é um serviço essencial, porque lei assim o determina. Contudo, nem todo serviço essencial é serviço público. A Lei 7.783, de 28 de junho de 1989, conhecida como Lei da Greve, por determinação do art. $9^{\circ}, \S 1^{\text {o }}$ da Constituição Federal de 1988, enumera serviços ou atividades essenciais, em seu art. 10. Considerando o conceito estrito de serviço público adotado nesse trabalho, a distribuição de medicamentos e alimentos ou compensação bancária, por exemplo, não se enquadram nessa noção. No 
entanto, independente da definição de serviço público, são serviços essenciais em razão do interesse público, por previsão legal.

Note-se que telecomunicações, de acordo com a Lei de Greve, é serviço essencial. A essencialidade é um dos elementos que caracteriza um serviço público. Tanto é assim que, de acordo com a LGT, uma parte dos serviços de telecomunicações, aqueles prestados em regime público, será assegurada pela União e, em razão dessa característica somada as demais, será serviço público (art. 64 da LGT). Contudo, isso não significa que todos os serviços de telecomunicações sejam públicos.

Segundo JÈZE (1928, p. 290),

Son única e exclusivamente servicios públicos aquellas necesidades de interés general que los gobernantes en cierto país y en una época determinada han resuelto satisfacer por procedimiento del servicio público. Sólo importa considerar la intención de los gobernantes. La opinión de los tratadistas carece de interés. El criterio personal del jurista que resuelve la dificultad es indiferente.

$\mathrm{O}$ art. 64 da LGT determina que as prestações em regime público do setor de telecomunicações ocorram sempre e quando "a própria União comprometa-se a assegurar" a existência, a continuidade e a universalização de serviços. Ora, se a União decide assegurar a prestação de um serviço, ainda que por meio de delegação, significa haver uma indispensabilidade de uma modalidade de serviço à promoção do bem comum.

Ressalta-se que, em telecomunicações, considerar uma modalidade de serviço como serviço público não exclui necessariamente a possibilidade de que essa mesma modalidade seja prestada por particulares autorizados. Cabe à União decidir se a modalidade de serviço será prestada exclusivamente em regime público ou, em concomitância, em regime privado.

A própria LGT incluiu, entre as diversas modalidades de serviço que poderiam ser prestadas em regime público, o Serviço Telefônico Fixo Comutado (STFC), de qualquer âmbito, destinado ao uso do público em geral. O Plano Geral de Outorgas (PGO), aprovado pelo Decreto $\mathrm{n}^{\circ} 2.534$, de 2 de abril de 1998, posteriormente alterado pelo Decreto $\mathrm{n}^{\circ} 6.654$, de 20 de novembro de 2008, determinou que o STFC pudesse ser prestado em ambos os regimes. Em outras palavras, a única modalidade de serviço prestado no regime público também é prestada no regime privado. ${ }^{17}$

${ }^{17}$ Cita-se a Oi (Telemar S.A.) como exemplo de concessionária, que presta o STFC local sob regime público e a GVT (Global Village Telecom Ltda.), como exemplo histórico de autorizada, posteriormente adquirida pela Telefônica, que prestava STFC local no regime privado. 
Mediante decreto do Poder Executivo, é possível a inclusão de novas modalidades de serviço em regime público (art. 18 da LGT e art. 16 da Res. 73, da ANATEL). Porém, passados 16 anos da entrada da lei em vigor, até o momento, nenhum outro serviço, além do STFC, foi inserido no rol do regime público. Entende-se, pela sistemática da LGT, que as modalidades não enumeradas pela União para prestação em regime público são prestadas mediante autorização, no regime privado.

Em síntese, no regime público do setor de telecomunicações, a titularidade do serviço prestado é da União, que delega um direito à gestão de um serviço por meio de concessão ou permissão, garantido que a remuneração se dê por meio de tarifa e exige o cumprimento de princípios específicos. Verifica-se que as quatro características do serviço público são observadas nos serviços de telecomunicações prestados no regime público. Alinha-se a conclusão de Alexandre Santos de Aragão: "a definição de 'regime público' prevista na LGT identifica-se com a de serviço público" (ARAGÃO, 2007, p. 271).

Por outro lado, não há consenso acerca da titularidade dos serviços outorgados mediante autorização. Isso porque não há acordo sobre a interpretação dos arts. 21, XI e 175 da Constituição Federal de 1988. Tampouco se observa, no âmbito do regime privado, artigo similar ao art. 64 da LGT.

Pela análise isolada do art. 21, XI da Constituição, é possível dizer que a União é titular dos serviços de telecomunicações e a autorização é uma forma de delegação de serviço público. Contudo, como já mencionado, o art. 175 da Constituição Federal determina que o serviço a ser assegurado por ente federativo pode ser delegado apenas por meio de concessão ou permissão. Para combinar esses dois artigos constitucionais hierarquicamente equivalentes, existem algumas interpretações possíveis.

Para concluir sobre a existência de serviço público outorgado mediante autorização, deve-se admitir que o constituinte olvidou-se de mencionar a autorização entre as modalidades de delegação de serviços públicos, ao lado da permissão e da concessão do art. 175 da Constituição Federal de 1988. Alternativamente, é possível defender que o constituinte introduziu erroneamente o regime de autorização para um serviço público no art. 21 , XI e XII da Constituição Federal de 1988, estabelecendo-se um conflito com o art. 175 .

Parece ser mais acertada a interpretação, ao menos até que advenha alguma Emenda Constitucional ao art. 175 da Constituição, de que os serviços citados no art. 21 da Constituição Federal de 1988, delegados mediante concessão ou permissão (art. 175 da CF/88) seriam serviços públicos; enquanto os serviços prestados mediante autorização não seriam serviço público e sim uma atividade econômica regulada. 
A seguir, aprofunda-se o tema, considerando a autorização na LGT. Para tanto, convém mencionar posições de alguns doutrinadores. Nesse sentido, a primeira de todas as providências é verificar se o termo autorização, do art. 21, XI da Constituição Federal de 1988, coincide com o referido na LGT.

Sobre o vocábulo "autorização" usado na LGT, Di Pietro afirma que ele não se amolda "ao conceito doutrinário. O uso indevido do vocábulo não justifica a alteração do conceito" (DI PIETRO, 2012, p. 234). Ela afirma que a LGT quis, na realidade, dizer licença ao invés de autorização (DI PIETRO, 2011, p. 138). Não restam claro, então, quais seriam as hipóteses de autorização para interesse exclusivo do autorizado e como seu conceito se ajusta à LGT.

Explica-se. É imperativo legal, premissa, portanto, que, no âmbito do regime privado, a outorga de serviço dê-se mediante autorização. Admitindo-se a ratio da autora, de que a outorga de autorização dar-se-ia no interesse exclusivo do autorizado, ter-se-ia a possibilidade de que, em casos de interesse restrito - como, por exemplo, o serviço de Radioamador - houvesse autorização no sentido constitucional. Nesse caso, estar-se-ia diante de uma autorização nos termos da lei e nos termos da autora.

Contudo, há situações em que a proposta da autora não se aplica. Observe-se que é, também, no âmbito do regime privado que se confere a outorga de Serviço Móvel Pessoal (SMP), que tem abrangência de interesse coletivo. Neste caso, para a autora, as regras da autorização da LGT se transmutariam no conceito de licença e não da autorização descrita da Constituição. Todavia, se assim for, considerando que a outorga do SMP (telefonia móvel) não seria autorização nos termos constitucionais, ter-se-ia uma quarta modalidade de outorga. Mais, para uma mesma regra geral de autorização na LGT, haveria serviços autorizados no sentido da Constituição e serviços licenciados nos termos da doutrina.

Entende-se não ser lógico ter mais de uma interpretação à definição de autorização de serviço referida na Constituição e na LGT. Não se justifica a imposição de entendimentos doutrinários passados, considerando o advento de norma legal que aponta para novos direcionamentos. Fato é que a LGT estabelece regras em consonância com a Constituição Federal de 1988 e os instrumentos de outorga em telecomunicações são: a concessão, a permissão e a autorização. Não há por que se falar em uma quarta modalidade, além das normas legais, para que os pensamentos doutrinários se enquadrem.

Ultrapassado esse ponto, há de se mencionar a discussão sobre a natureza jurídica da autorização: seria ou não serviço público? Frequentemente, essa discussão é relacionada à titularidade do serviço.

Nesse primeiro momento, todavia, o foco a seguir será a classificação dos serviços. O maior argumento daqueles que defendem a autorização como forma de delegação de serviço público é a afirmação de titularidade da União em 
relação aos serviços constantes no art. 21. Considerando esse raciocínio, Farias ${ }^{18}$ entende que a titularidade dos serviços autorizados da LGT é da União; logo, esses serviços têm natureza de públicos, independente de o regime legal ser privado. Na mesma linha, Grotti entende que a LGT foi contrária à concepção tradicional de serviços públicos, na qual se prega a prestação, total ou parcial, sob o regime de direito público. Segundo sua interpretação, a LGT possibilitou que serviços públicos sejam prestados exclusivamente no regime privado. (GROTTI, 2006, p. 207).

Esses argumentos não apresentam explicação razoável para conjugar o art. 21 ao art. 175 da Constituição Federal de 1988. Lembre-se de que este último, expressamente, determina que a delegação de serviço público se dê por meio de concessão e permissão. Ou seja, o constituinte ou esqueceu-se de mencionar autorização no art. 175 da CF/88 ou introduziu, erroneamente, o termo autorização no art. 21 da CF/88.

Admitir que, tanto no regime público quanto no privado da LGT, está-se diante de serviço público parece enfraquecer o sistema desenvolvido pela lei, além de ignorar o elemento formal do serviço público que auxilia o entendimento dessa discussão: é dizer, o serviço público possui um regime especial, público. É importante ressaltar que, no regime público, a LGT garante que a União assegure a manutenção do serviço, admite a delegação por concessão ou permissão (coadunando-se com o art. 175 da Constituição Federal), exige o cumprimento dos princípios do serviço público e prevê remuneração por tarifa, enquanto, no outro regime privado, as regras são mais fluidas.

Considerando o desenho da LGT e reavivando o ensinamento de Jèze sobre a importância de um regime próprio do serviço público, parece não haver lógica jurídica em estabelecer diferenciações entre os regimes para, ao final, classificá-los como públicos. Nesse sentido, acompanha-se o posicionamento de Carvalho Filho, ${ }^{19}$ Alexandre de Aragão, ${ }^{20}$ Roberto Dromi ${ }^{21}$ e Floriano Marques ${ }^{22}$ que relacionam a natureza do serviço com o regime em que é prestado.

\footnotetext{
${ }^{18}$ Segundo FARIAS (2005, p. 116), ontologicamente, as atividades arroladas no art. 21, incisos XI e XII (quando executadas mediante autorização), continuam a ser tratadas como serviços públicos. Entretanto, sua disciplina legal pode atender a um outro regime, pautado nos princípios inerentes às atividades econômicas que, por conta do princípio da livre iniciativa - art. $1^{\circ}$, IV da Constituição Federal de 1988 - não pode ser afastado da noção de serviço público naquilo que não seja indispensável para o atendimento do interesse geral.

${ }^{19}$ Para CARVALHO FILHO (2013, p. 448). "Em nosso entender, ou a atividade se caracteriza efetivamente como serviço público - hipótese em que poderá este ser prestado por concessão ou por permissão (mas não por autorização) - ou se tratará de atividade meramente privada e, aí sim, poderá ser outorgada a autorização. Além disso, se o serviço
} 
A seguir, enfrenta-se o tema da titularidade conjugando os arts. 21 e 175 da Constituição Federal de 1988. Alexandre Ditzel Faraco apresenta uma solução conciliatória entre os dois artigos, sem abrir mão da titularidade da União. Ele sugere que apenas serão classificadas como serviço público aquelas atividades econômicas que a Constituição, por meio de menção expressa, tiver assegurada a prestação. Havendo essa menção, o legislador ordinário não pode se afastar dessa realidade. Em sua tese, como o art. 175 da Constituição Federal de 1988 não cita a expressão autorização mencionada no art. 21, o ente público, titular da atividade ${ }^{23}$ pode escolher a forma pela qual deve ser feita a prestação das autorizações. (FARACO, 2003, p. 125)

Essa percepção é interessante por reconhecer que os serviços prestados em regime privado, sob a autorização, não são serviços públicos. É dizer, mesmo que se admita que a titularidade do serviço seja do Estado, as demais características dos serviços públicos não são observadas e, consequentemente, os serviços prestados em regime privado são atividades típicas da iniciativa privada.

Há, ainda, outra forma de conciliar os arts. 21, XI e 175 da Constituição: as atividades relacionadas no art. 21 não são obrigatoriamente de titularidade da União. Segundo Alexandre de Aragão, a Constituição dá ao legislador a discricionariedade para enquadrar as atividades nele descritas ou como serviço público ou como privado de interesse público sujeitas a uma regulação de natureza autorizativa (ARAGÃO, 2007, p. 226). Ele conclui que algumas dessas

é público, somente o regime de direito público poderá regulá-lo em seu perfil fundamental."

${ }^{20}$ Para ARAGÃO (2007, p. 225). "A questão é, sobretudo, de nomenclatura ('atividades privadas de interesse público' versus 'serviços públicos virtuais'), uma vez que a distinção de regime jurídico entre essas atividades de interesse coletivo exercidas ou titularizadas pelo Estado (serviços públicos propriamente ditos) é, como já exposto, evidente. Assim, se o regime jurídico - que é o que importa - é diverso, a inclusão das duas categorias de atividade no mesmo conceito (de serviço público) faria com que este, por sua amplitude, acabasse ficando sem conteúdo."

${ }^{21}$ Para DROMI (1996, p. 531). "El obrar público, sin distinción de sus ejecutantes, tiene inexorablemente que estar regido en todo o en parte por el derecho público. Lo contrario provoca -y la realidad lo acredita- una distorsión peligrosa de inversión de regímenes jurídicos, afiliándose el Estado al régimen jurídico privado, o los particulares sometidos al peso de las cargas públicas."

${ }^{22}$ MARQUES NETO et al. (2011, p. 52) entende que a LGT confere a condição de serviço público (em sentido estrito) aos serviços de telecomunicações prestados em regime público. Aos demais serviços, o tratamento dedicado é o de atividades econômicas (em sentido estrito) a serem explorados sob o típico regime de direito privado.

${ }^{23}$ FARACO (2003, p. 127) entende que, mesmo nos serviços prestados em regime privado de telecomunicações, estar-se-ia diante de uma atividade econômica de titularidade do Estado. Se a Constituição não estabelece o regime de serviço público, o legislador ordinário é livre para estabelecer outro regime. 
atividades, mais do que delegadas à iniciativa privada sob a titularidade do Estado, "teriam saído da órbita público-estatal e passado para o mercado, para a livre iniciativa privada, sujeitas, naturalmente, à regulação exógena" (ARAGÃO, 2007, p. 227).

$\mathrm{Na}$ mesma linha, Helena de Araújo Lopes Xavier afirma que, considerando o art. 170, parágrafo único da Constituição Federal de 1988, a autorização outorgada no regime privado da LGT "é um condicionamento ao exercício do direito de livre iniciativa, cujo estabelecimento traduz o reconhecimento de que o correspondente direito é pré-existente na titularidade dos particulares" (XAVIER, 2003, p. 38). Nesse sentido, justifica-se o ato de autorização ser declaratório e vinculado.

Para Alexandre de Aragão - seguindo o mesmo entendimento de Laender (2005, p. 232-233) -, a autorização do art. 21 da Constituição Federal de 1988 é originada do poder de polícia do Estado. ${ }^{24}$ Tanto o poder de polícia como o serviço público são formas de intervenção do Estado na atividade econômica. Segundo Daniel Edgardo Maljar (2007, p. 169), serviço público pressupõe a titularidade da Administração, enquanto o poder de polícia regula a atividade por meio de normas, o exercício de atividades por particulares em razão do direito constitucional da iniciativa privada. Nesse sentido, a atividade de polícia administrativa não se confunde com serviços públicos. Esses consistem em prestações positivas aos indivíduos, enquanto aquele impõe limitações aos indivíduos em benefício da coletividade. No poder de polícia, a Administração Pública condiciona a atividade particular; pelo serviço público; ela confere utilidades aos particulares (ARAGÃO, 2012, p. 190).

Vale lembrar, por fím, os ensinamentos de que os serviços públicos variam no tempo e no espaço. No passado, a Constituição considerou todos os serviços de telecomunicações como públicos. Contudo, a Emenda Constitucional $\mathrm{n}^{\mathrm{o}}$ 8/95 alterou essa perspectiva, como bem mencionou o Ministro-Relator Marco Aurélio em seu voto na Arguição de Descumprimento de Preceito Fundamental (ADPF) n $n^{\circ}$ 46/DF, que julgou a existência ou não de privilégio no serviço postal. Acredita-se que, após a EC no 8/95 e advento da LGT, desenhou-se um novo cenário no direito nacional. Já não são públicos todos os serviços de telecomunicação. A natureza dos serviços está relacionada ao regime e a forma de outorga. ${ }^{25}$

${ }^{24}$ ARAGÃO (2007, p. 232) enfatiza que "Cumpre também destacar que o art. 21 (...) dispõe (...) que essas atividades são da competência da União, que as regulará seja como poder concedente, seja como titular do poder de polícia autorizativo sobre elas incidente." ${ }^{25} \mathrm{Na}$ ADI n ${ }^{\circ} 1.668-5 / \mathrm{DF}$, de 1998, entre outras alegações, busca-se a declaração de inconstitucionalidade do art. 65, III, que permite a concomitância do regime público e do regime privado. Vencido o ministro-relator Marco Aurelio no pedido de suspensão cautelar, o Supremo entendeu pela constitucionalidade desse inciso. Passados 10 anos da 
Pelo exposto, ratifica-se o entendimento de que os serviços de telecomunicações autorizados, referidos no art. 21 da Constituição Federal de 1988, e que ganham significado na LGT, não são serviço público. Trata-se de um serviço de titularidade da iniciativa privada, ainda que regulado pelo Estado. Este estudo filia-se, portanto, ao posicionamento que considera que os serviços outorgados mediante autorização não têm natureza de públicos e estão sujeitos ao exercício do poder de polícia.

\section{Amplicação do Acesso no Setor de Telecomunicações}

Até o momento, ressaltou-se uma diferença entre os regimes público e privado no setor de telecomunicações. O prisma central da distinção foi a de estabelecer que, no regime público, os serviços prestados sob a concessão ou permissão têm a natureza pública, enquanto que, no regime privado, os serviços são abertos à livre iniciativa desde que cumpridos requisitos. Essa realidade não apaga outra: os serviços prestados em regime privado são regulados; há influência do direito público na livre iniciativa. A ANATEL pode impor condicionamentos e novas regulamentações tanto aos já autorizados como aos entrantes (arts. 130 e 135 da LGT). Esse tema será abordado sob a perspectiva da massificação.

A seguir, busca-se estabelecer um vínculo comum entre os dois regimes do setor: a ampliação do acesso. A universalização, no regime público, e a massificação, no regime privado, guardam especial interseção, embora também apresentem características jurídicas distintas.

decisão, o mesmo ministro-relator parece ter mudado de opinião. Afirma o Ministro em seu voto: "A possibilidade de duplo regime quanto à prestação do serviço foi inserida no nosso ordenamento por meio da Lei ${ }^{\circ} 9.472$, de 1997 , quando consignou que, no caso das telecomunicações, poderia coexistir o regime público e privado. E, para afastar essa aparente, porque falsa, dicotomia entre serviço público e atividade econômica é que o Constituinte derivado houve por bem retificar o adjetivo 'público', que qualifica o serviço de telecomunicações, isso quando da Emenda no 8, de 1995. Desse modo, o texto atual remete ao 'serviço de telecomunicações' quando versa sobre competência da União para explorá-lo diretamente ou mediante autorização, concessão ou permissão, e não mais ao "serviço público de telecomunicações." (fls. 71 e 72 do voto do Ministro Marco Aurélio. BRASIL. Supremo Tribunal Federal. Arguição de Descumprimento de Preceito Fundamental. ADPF n 46/DF. Tribunal Pleno. Arguente: Associação Brasileira das Empresas de Distribuição. Arguido(a/s): Empresa Brasileira de Correios e Telégrafos. Intimado(a/s): Sindicato Nacional das Empresas de Encomendas Expressas; Associação Brasileira de Empresas de Transporte Internacional. Relator(a): Min. Marco Aurélio. Relator para Acórdão: Min. Eros Grau. Brasília, 5 de agosto de 2009. Cumpre mencionar que, embora nessa ADPF, o Ministro Marco Aurelio restou vencido, os argumentos acima transcritos sobre o setor de telecomunicações não foram contestados nos demais votos dos Ministros. 
Inicialmente, é preciso mencionar que o princípio da generalidade, universalidade ou universalização ${ }^{26}$ deve ser eficaz e integrar a política social e econômica. De forma sucinta: "Universalizar significa tornar determinada categoria de serviço fruível por todos os segmentos sociais, de forma ampla e sem limitações decorrentes de condicionantes econômicas, geográficas ou culturais." (FARACO et al., 2003, p. 9-10).

O Direito reflete e preocupa-se em efetivar o princípio da universalização por meio de distintas regulamentações conjugadas com atuações políticas. No direito público, o conceito de universalização, frequentemente, aparece relacionado à prestação de serviço público, como um princípio. Importa destacar que, nos serviços regulados pelo Estado, de natureza pública ou não, a universalização visa a que todos tenham direito ao acesso e à fruição do serviço, ofertados a preços adequados e com qualidade. É sob essa perspectiva que se deve estudar o setor de telecomunicações.

Antes, porém, ressaltam-se dois posicionamentos da União Internacional de Telecomunicações (UIT), ${ }^{27}$ da qual o Brasil é Estado-Membro, sobre os chamados serviços universais. Em 1993, ao se discutir o tema, optou-se por não se definir serviço universal, mas, estabelecer elementos que o comporiam: (i) acesso a telefones; (ii) disponibilização e possibilidade de cobrança pelo serviço; (iii) oferta residual (ofertado àqueles em cujo o mercado não se tem interesse econômico); (iv) desenvolvimento de infraestrutura; e, (v) oferta de alguns serviços de telecomunicações como garantia de um mínimo, básico (ONU/UIT 1993).

Já em 1998, a UIT estabeleceu um conceito, ${ }^{28}$ considerando que o objetivo dos serviços universais é facilitar a comunicação entre todos os membros da sociedade, não se restringindo a um nível mínimo (ou básico) de telecomunicações. Ao contrário, por decisão política regulatória, poder-se-ia obrigar os operadores a ofertar seus serviços a toda população.

\footnotetext{
${ }^{26}$ Não há unanimidade em definir o principio da universalidade ou generalidade como de universalização, Marques Neto (2006, 77-8) e Bielschowsky $(2010,179)$.

${ }^{27}$ A UIT é a Agência do Sistema das Nações Unidas dedicada a temas relacionados às Tecnologias da Informação e Comunicação (TICs). Atualmente, o principal objetivo da UIT é "Conectar o Mundo" por meio da mobilização de recursos humanos, técnicos e financeiros necessários ao alcance das metas de conectividade estabelecidas no marco da Cúpula Mundial sobre a Sociedade da Informação (CMSI) e redução do hiato digital. Para mais detalhes visitar: www.itu.int

${ }^{28}$ OUN/UIT (1998): "universal service is long-term objective of making communication facilities available to every member of society on an individual or household basis, and it is used in particular in the regulatory-legislative framework to indicate the obligation of telecommunication operators to provide their services to the entire population."
} 
O marco regulatório brasileiro, ao desenhar a universalização plasmada na LGT, reflete prioritariamente a primeira proposta de entendimento adotada pela UIT em 1993.

\section{Universalização na LGT}

Como mencionado na introdução deste artigo, a Lei Geral de Telecomunicações insere-se em um contexto político nacional e internacional de mudanças. Nesse sentido, é preciso reconhecer que as discussões internacionais influenciaram a formação do conceito de universalização na LGT. É, também, imperioso reconhecer que o termo "universalização" ganhou contornos próprios na LGT. No setor de telecomunicações, ele está restrito ao regime público.

Após a quebra do monopólio do setor (EC nº 08/1995, em 10 de dezembro de 1996), o Ministro das Comunicações encaminhou o projeto de lei com a Exposição de Motivos no 231/MC. Esse documento, constantemente citado em trabalhos sobre o setor, é importante por apresentar breve histórico e o pensamento daquela época que, evidentemente, influenciou o modo como o projeto de lei foi elaborado.

Nele, a universalização "do acesso aos serviços básicos” aparece como um dos objetivos fundamentais da reformulação do setor (BRASIL. Min. das Comunicações, 1996, p. 15-16). Destaca-se, pois, que a ideia ali contida é, fundamentalmente, de universalizar os serviços básicos, ou seja, os serviços públicos.

No arcabouço regulatório, presumindo-se que os consumidores economicamente atrativos são atendidos satisfatoriamente por um mercado competitivo, a universalização (BRASIL. Min. das Comunicações 1996, 18) é pensada sobre duas situações genéricas: (i) serviços de telecomunicações individuais, com qualidade, tarifas e prazos razoáveis, a qualquer pessoa que os requisitar; e, (ii) prover os serviços em localidades remotas no interior do País, nas áreas rurais, nas periferias das grandes cidades, em regiões escassamente povoadas. Para essa última situação, há previsão de mecanismos de financiamento.

Apesar de a LGT ter sido elaborada também com consultores internacionais, o marco regulatório brasileiro reflete basicamente a primeira proposta de entendimento da UIT de 1993. Na exposição de motivos, fala-se, prioritariamente, em serviços mínimos (telefonia fixa) e em desenvolvimento de infraestrutura para aumentar a cobertura dos serviços. A universalização tem um caráter residual; é subsidiada e promove o acesso em locais economicamente desinteressantes.

É, pois, com base no contexto acima referido que a LGT entra em vigor. Nela, no art. 79, se definem obrigações de universalização como aquelas que possibilitam acesso de todos, pessoas ou instituições de interesse público, aos 
serviços de telecomunicações, "independentemente de sua localização e condição socioeconômica, bem como as destinadas a permitir a utilização das telecomunicações em serviços essenciais de interesse público."

Como se observa, a definição resume o conceito de universalização, em geral, e no contexto das telecomunicações. Contudo, sua abrangência acaba por se restringir ao regime público por força dos arts. 63 e 64 da LGT. É dizer, há obrigação de universalização apenas para aqueles serviços que a União se compromete assegurar: os serviços públicos. Logo, apenas as concessionárias do STFC e prestadoras de serviço público têm o dever de universalizar a partir dos mecanismos estipulados na LGT. Repita-se que, até o momento, apenas o STFC foi incluído como modalidade de serviço a ser prestado no regime público.

Em suma, ainda que a definição de universalização aparentemente seja ampla, a própria lei restringiu seu conceito ao regime público, estabelecendo obrigações e mecanismos específicos no regime público. Universalização na LGT é sinônimo de princípio da universalização nos serviços públicos.

\section{Mecanismos de Universalização}

A universalização dos serviços de telecomunicações dá-se por meio de políticas públicas que visem garantir acesso e fruição dos serviços prestados em regime público ao maior número de usuários.

A estruturação das políticas de universalização cabe à ANATEL que, após estudos, encaminha proposta ao Ministério das Comunicações e este, após debates, a encaminha para edição de Decreto do Presidente da República. Finalmente, essas políticas são aplicadas e fiscalizadas pela Agência (arts. 19, I, III, XXX e 22, III da LGT). Trata-se de uma repartição de atribuições entre política e técnica "uma vez que supõe um regime de relações institucionais entre o Governo e a ANATEL com o escopo de preservar os valores democráticos e a necessidade da atuação técnica da agência reguladora." (D’ALBUQUERQUE, 2013, p. 95).

Evidentemente, o regulador não pode impor a universalização e a penetração da telefonia sem considerar aspectos econômicos, pois políticas sociais e econômicas devem ser complementares. Para tanto, a LGT estabeleceu dois planos de universalização com fontes de financiamento distintas; são dois pilares que sustentam o conceito de universalização no regime público. Em ambos, a execução é de responsabilidade das concessionárias.

O primeiro é o Plano Geral de Metas para a Universalização (PGMU) que, pelo estabelecido em lei, deriva de obrigação contratual. Logo, para a implementação desse plano, as concessionárias concorrem com seus próprios recursos. No PGMU, podem ser incluídas obrigações que a Agência e o Governo entendem prioritárias para permitir o acesso às telecomunicações, desde que não interfiram no equilíbrio econômico financeiro da concessão. 
O segundo pilar é o Plano de Metas de Universalização (PMU), financiado pelo Fust. A LGT determinou a criação do Fust em seu art. 81 e a Lei $\mathrm{n}^{\mathrm{o}}$ 9.998, de 17 de agosto de 2000, instituiu-o. O PMU deve conter propostas, consonantes com a Lei do Fust, de acesso/obrigações de universalização de serviços de telecomunicações, cujos investimentos não são recuperáveis, mesmo com uma exploração eficiente do serviço. Reconhece-se que nem todo custo de políticas de universalização pode ser imputado em sua totalidade às concessionárias, uma vez que algumas dessas políticas podem não ser economicamente recuperáveis. O PMU é um típico instrumento de políticas públicas: não se exige que o projeto seja economicamente viável.

Não é intenção minudenciar o PGMU e o PMU e seus resultados em alcançar um serviço mínimo. Cumpre apenas destacar alguns pontos.

Só se desenvolveu PGMU e PMU para as concessionárias de STFC, uma vez que apenas parte do STFC está inserida no regime público. O PGMU está em sua terceira edição, enquanto o Governo só aprovou um PMU.

As metas estabelecidas nos PGMUs priorizaram o acesso individual do STFC. No PGMU I (BRASIL, Presidência da República, 1998), a obrigação era de prover acessos individuais a localidades com mais de 600 habitantes. No PGMU II (BRASIL, Presidência da República, 2003), os acessos individuais deveriam ser instalados em localidades com mais de 300 habitantes. O PGMU III (BRASIL, Presidência da República, 2011) manteve a obrigação de atendimento em localidades com mais de 300 habitantes.

Contudo, não basta disponibilizar infraestrutura. "Há que se garantir meio de acesso economicamente ao serviço, o que compreenderá, no curso da progressiva universalização, necessariamente, a oferta de estruturas tarifárias diferençadas" (MARQUES NETO, 2006, p. 85). Nesse sentido, o PGMU II estabelece o Acesso Individual Classe Especial (AICE) ou "telefone popular". Trata-se de uma modalidade de serviço pré-pago para uso residencial e limitado a um acesso por domicílio. No PGMU III, o AICE ganha novos contornos porque restringe o benefício àquelas famílias inscritas no Cadastro Único dos Programas Sociais do Governo Federal.

Os PGMUs também se preocuparam em estabelecer metas de acessos coletivos. Isso significa garantir a existência de Telefones de Uso Público (TUP). Desde o primeiro PGMU, estabeleceram-se 300 metros como distância máxima entre os TUP em uma mesma localidade. Contudo, a densidade de TUP por 1000 habitantes tem diminuído ao longo do tempo. O PGMU I previu uma densidade de 7,5; o PGMU II de 6; e, o PGMU III de 4. Justificou-se essa diminuição pela baixa utilização do serviço nos grandes centros, onde a concentração da população é maior.

Por outro lado, se o PGMU I obrigava a instalação de TUP para as localidades com 300 habitantes; no PGMU II, tal obrigatoriedade passou a ser 
para as localidades com 100 habitantes. No PGMU III, a regra se manteve. Note-se que, embora, nessas localidades não haja obrigação de acesso individual, optou-se por garantir um serviço mínimo para a comunicação.

No PGMU III, estabeleceram-se locais em que os TUPs deveriam ser instalados mediantes solicitação e disponibilidade, independente do quantitativo de habitantes, tais como: hospitais e escolas públicas, quilombolas, população extrativista, assentamentos rurais e aldeias indígenas. Por fim, o PGMU III estabeleceu que 2,5\% dos TUPs devem estar adaptados para comunicação das pessoas com deficiência de fala, audição e locomoção. O PGMU II determinava a adaptação de $2 \%$. Essas regras também objetivavam garantir o mínimo de comunicação.

Repita-se: todos esses avanços na ampliação do acesso à telefonia determinados pelo PGMU são obrigações de natureza contratual. Por isso, os custos são de responsabilidade da própria concessionária.

O outro mecanismo de universalização estabelecido em lei é o PMU que, embora executado pelas concessionárias, tem seu financiamento com recursos arrecadados pelo Fust. Como dito, o Fust é um fundo previsto no art. 81 da LGT e criado pela Lei $n^{\circ}$ 9.998, de 17 de agosto de 2000. Em 2001, o Fundo passou a ser recolhido. Somente em junho de 2008, o Ministério das Comunicações, por meio da Portaria $n^{\circ} 273$, de 3 de junho de 2008, aprovou a Norma $n^{\circ} 01 / 2008$, que estabeleceu os procedimentos para eleição de projetos a serem financiados com os recursos do Fundo.

Antes mesmo dessa norma, muitas foram as tentativas de aprovar projetos; apenas um, até o momento, concretizou-se em PMU. Trata-se de um Programa de Atendimento à Pessoa com Deficiência, aprovado pela Portaria do Ministério das Comunicações no 263, de 27 de abril de 2006. Após os trâmites, editou-se o Decreto $\mathrm{n}^{\circ}$ 6.039, de 7 de fevereiro de 2007, conhecido como PMU I.

Esse plano previu que as instituições cadastradas no Sistema Nacional de Informações sobre Deficiência (Sicorde) da Secretaria de Direitos Humanos (SDH), vinculadas à Presidência da República, teriam direito à instalação e à manutenção de equipamentos que possibilitem a comunicação, via telefone fixo, das pessoas com deficiência auditiva. Além disso, essas instituições teriam a isenção mensal da assinatura básica, sendo garantida uma franquia de minutos em chamadas locais.

O Decreto do PMU I previu o estabelecimento de metas trimestrais de instalações, calculando-se que todas as instituições seriam atendidas em nove meses, a partir da celebração do Termo de Obrigações entre ANATEL e concessionárias. O Termo foi assinado em 5 de setembro de 2007 e a previsão de que 782 instituições seriam atendidas em benefício de 19 mil pessoas com deficiência auditiva não se cumpriu. 
Das 782 instituições previstas, cerca de 100 aderiram ao Programa. Apuradas as obrigações desse PMU, estimou-se que, em valores reajustados, serão ressarcidos às concessionárias pouco menos de $\mathrm{R} \$ 200.000,00$ dos quase $\mathrm{R} \$ \quad 12,5$ bilhões ${ }^{29}$ arrecadados ao Fust até dezembro de 2012 (D’ALBUQUERQUE, 2013, p. 137).

Dos mecanismos de universalização acima expostos, é fundamental dizer que o PGMU, alinhado ao ambiente concorrencial, especialmente após a desestatização do setor, foi um grande impulsionador do acesso às telecomunicações. O STFC foi o primeiro serviço a chegar a todos os municípios do Brasil. Contudo, como sabido, o mercado de telecomunicação é muito dinâmico e evolui tecnologicamente de forma acelerada. Hoje, a demanda social parece exigir, na maior parte dos casos, mais do que um mínimo de comunicação. Ressalta-se que essa tendência alinha-se à segunda proposta de definição de serviço universal adotada pela UIT.

\section{Universalização e Concorrência}

O modelo proposto pela LGT é de não exclusão ou oposição entre universalização e concorrência e, sim, de complementaridade. "A LGT foi sábia em equilibrar estas duas vertentes, franqueando ao poder público e especialmente ao órgão regulador mecanismos para promover a universalização sem comprometer a competição." (MARQUES NETO, 2006, p. 86)

Normalmente, a doutrina destaca essa característica considerando o fato de, no novo modelo regulatório, admitirem-se empresas autorizadas (e não apenas as concessionárias) prestando o serviço de telefonia fixa $(\mathrm{STFC})^{30}$, é dizer: concessionárias e autorizadas são concorrentes. Helena de Araújo Lopes Xavier destaca, ainda, que o sistema de competição desenhado na LGT permite que as concessionárias concorram entre si, "recusando assim caráter de exclusividade ou privilégio ao contrato de concessão, conforme dispõe o art. 84, caput, da LGT.” (XAVIER, 2003, p. 43)

Note-se que, à medida que a concorrência cresce, os agentes econômicos buscam reduzir preços e explorar demandas reprimidas para conquistar maior participação no mercado. Por sua vez, em um ambiente competitivo, os usuários de serviços têm mais possibilidade de escolha e, consequentemente, exigem mais qualidade do serviço a um menor custo.

${ }^{29}$ No final de dezembro de 2013 o FUST já havia arrecadado pouco mais de 16 bilhões, segundo números obtidos junto a ANATEL em 2014.

${ }^{30} \mathrm{O}$ primeiro Plano Geral de Outorgas (PGO), aprovado pelo Decreto $\mathrm{n}^{\circ} 2.534$, de 02 de abril de 1998, determinou que o STFC pudesse ser prestado em ambos os regimes. O mesmo documento ratificou que os demais serviços seriam submetidos ao regime privado. 
Contudo, sabe-se que apenas a concorrência mercadológica não garante acesso aos serviços de telecomunicações a toda a população, nem necessariamente uma qualidade mínima do serviço. Isso porque é característica da livre iniciativa que os agentes econômicos invistam em mercados que lhes garantam rentabilidade econômica e de forma a captar o maior número de clientes.

Para que se alcance o acesso universal às telecomunicações, são necessárias políticas públicas e instrumentos de efetivação próprios. É preciso que se pense em políticas de universalização e, ao mesmo tempo, em instrumentos eficientes de regulação do mercado para que os benefícios sociais sejam alcançados.

\section{Massificação no Setor de Telecomunicações}

Até o momento, trabalhou-se o conceito de universalização no setor de telecomunicações, respeitando as delimitações legais estipuladas na LGT que dão àquele um contorno teórico bem definido. Sedimentado esse entendimento, é preciso avançar na discussão para mais bem entender a noção de massificação no setor de telecomunicações.

$\mathrm{O}$ art. $2^{\circ}$, I, II e VI da LGT, independente do regime jurídico, afirma que cumpre ao Poder Público garantir políticas de acesso às telecomunicações com tarifas e preços razoáveis ${ }^{31}$ e em condições adequadas. Além de estimular a expansão do uso de redes e serviços de modo a beneficiar a população e desenvolver econômica e socialmente o País. Isso porque os serviços de telecomunicações são considerados essenciais.

No regime público, a própria lei estabelece critérios rígidos para a ampliação do acesso com tarifas e condições adequadas que, como visto, é alcançado com o cumprimento dos princípios típicos dos serviços públicos, em especial do princípio da universalização.

O mesmo rigor não se observa no regime privado, uma vez que a lei o direciona a uma prestação de serviço mais livre e estabelece que a regulamentação deva respeitar os princípios constitucionais da atividade econômica. A princípio, o acesso é consequência da livre expansão das prestadoras autorizadas. Após a reestruturação do setor de telecomunicações, focalizou-se na expansão no serviço prestado em regime público. Como visto no item anterior, com as edições do PGMU, possibilitou-se que o STFC fosse o primeiro serviço de telecomunicações a atingir todos os municípios brasileiros.

Por outro lado, os serviços prestados no regime privado, tais como o serviço móvel pessoal (SMP - telefonia móvel) e o serviço de comunicação

${ }^{31}$ Note-se que ao mencionar tarifa e preço refere-se aos regimes público e privado. 
multimídia (SCM - também conhecido como banda larga fixa) se expandiram tendo em vista a demanda reprimida, avanços tecnológicos e interesses da iniciativa privada. Isso, contudo, não garantiu que todas as localidades fossem servidas. Foi constatada a necessidade de avançar. Nesse contexto, lembre-se da segunda proposta de definição de serviço universal da UIT que já não se focaliza em garantir serviço mínimo.

Em 2008, passados 10 anos da reestruturação, a Portaria $n^{\circ} 178$, de 22 de abril de 2008, do Ministério das Comunicações, indicou, na implantação de políticas públicas, que a ANATEL adotasse as seguintes diretrizes, entre outras: ampliar a oferta de serviços para o acesso à internet por meio de banda larga; reduzir as barreiras ao acesso e ao uso dos serviços de telecomunicações para as classes de menor renda; ampliar a oferta de todos os serviços de telecomunicações de interesse coletivo, nas diversas regiões do País; assegurar a competição e a concorrência na exploração de serviços, de modo a proporcionar os benefícios aos usuários em termos de preço e qualidade; e, criar ambiente favorável ao surgimento e fortalecimento de novos prestadores de serviços de telecomunicações de pequeno e médio porte.

A partir dessa determinação, que, pela redação, se concentrou no regime privado, ${ }^{32}$ a ANATEL, por meio da Resolução no 516 , de 30 de outubro de 2008, publicou o Plano Geral de Atualização da Regulamentação das Telecomunicações no Brasil (PGR). Trata-se de documento estratégico que apontou os rumos da regulação do setor para os 10 anos subsequentes.

A Resolução $n^{\circ} 516 / 2008$ enumera princípios regulatórios, previstos ou decorrentes da LGT, que orientam e balizam a atuação da ANATEL, entre outros: acelerar a redução das desigualdades regionais ${ }^{33}$ e possibilitar a oferta dos serviços de telecomunicações da forma mais homogênea possível em todo território nacional. ${ }^{34}$

Esses princípios dão origem a diversos objetivos que, por sua vez, estão relacionados a propósitos estratégicos e são concretizados por meio de ações para a atualização da regulamentação de curto, médio e longo prazo. O primeiro dos objetivos é a massificação do acesso em banda larga. Sobre o tema, admite a Resolução $\mathrm{n}^{\circ}$ 516, de 30 de outubro de 2008, da ANATEL a necessidade de massificar o acesso em banda larga para as diversas camadas da população para suprir a crescente demanda por conteúdo, aumentar a transmissão de dados em

\footnotetext{
${ }^{32}$ No regime público, há concessão apenas de STFC e as determinações da portaria referem-se à banda larga e à expansão dos serviços de telecomunicação.

${ }^{33}$ Item: "II.2. Acelerar a redução das desigualdades regionais" (Resolução nº 516, de 30 de outubro de 2008, da ANATEL).

${ }^{34}$ Item: "II.3. Ampliar a oferta e o uso de serviços e das redes de telecomunicações em todo o território brasileiro" (Resolução n 516, de 30 de outubro de 2008, da ANATEL).
} 
alta velocidade, superar do hiato digital, realizar a inclusão social, desenvolver aplicações específicas para cada segmento social. "O aumento da abrangência e da capilaridade do acesso garantirá a ampliação dos benefícios sociais (...), sendo que a competição, inclusive no que diz respeito às redes, deverá ser o vetor para a massificação do seu uso."

O propósito estratégico da massificação da banda larga é estimular tanto o surgimento de outros prestadores de acesso quanto o uso da infraestrutura existente. Note-se que, alinhado a um objetivo social de ampliar o acesso e uso das telecomunicações, há uma preocupação concorrencial, de estímulo à competição no mercado. A partir dessas premissas, pensou-se em ações de curto, médio e longo prazo.

Sem que o termo massificação seja encontrado na LGT, o PGR utilizou-o como expressão para indicar ampliação de acesso à banda larga. Desde então, outras Resoluções da ANATEL ${ }^{35}$ têm replicado essa determinação do PGR. A Resolução no 544, de 11 de agosto de 2010, em seus "considerandos", reconheceu a massificação do serviço móvel.

Em artigo comemorativo dos 20 anos da Constituição Federal, o então presidente da Agência afirmou que "a Anatel vem empreendendo ações com vistas à difusão e massificação de outros serviços, como os de telefonia móvel e os serviços de banda larga" (SARDENBERG, 2008, p. 397).

Diante disso, questiona-se: existe base legal e mecanismos que justifiquem a utilização de termos distintos para promover a ampliação do acesso dos serviços de telecomunicações?

Fernando Rocha e Eliana Leão, em obra publicada em 1999, afirmam, sem deixar de criticar, que, a partir da EC n ${ }^{\circ}$ 08/95, o Estado transfere a titularidade de atividades de telecomunicações que passam a ser exercidas como atividade econômica. Por outro lado, alertam para uma aparente, porém enganosa, dicotomia na distinção entre regime público e privado e para a necessidade de que todos os serviços de telecomunicações sejam universais e contínuos (ROCHA et al., 1999, p. 207 e 211). Eles defendem que, considerando o art. $2^{\circ}$ da LGT, independentemente do regime jurídico, em qualquer hipótese, e "a todo custo devem ser buscadas a universalização e a continuidade do serviço. (...) Negar tal evidência é rasgar os cânones

${ }^{35}$ Resolução no 556, de 20 de dezembro de 2010; Resolução no 557, de 20 de dezembro de 2010; e, Resolução $n^{\circ}$ 558, de 20 de dezembro de 2010. As três, ao justificarem a edição de seus respectivos regulamentos, citam que o PGR estabelece a massificação do acesso em banda larga. A Resolução nº 629, de 16 de dezembro de 2013, cita, no art. 22, V do Regulamento de celebração e acompanhamento de Termo de Compromisso de Ajustamento de Conduta (TAC), a expressão massificação. 
constitucionais, sobrepondo os interesses particulares aos da coletividade" (Rocha et al. 1999, 212).

Essa enérgica conclusão talvez tenha raiz em uma confusa interpretação da própria LGT e da distinção entre os regimes público e privado nela estabelecidos. Logo, não é possível concordar que a universalização e a continuidade, tal qual referidas na LGT, se estendam a todos os serviços de telecomunicações. Isso porque, como já demonstrado, esses princípios possuem sistemáticas próprias no regime público.

Cumpre observar que, talvez, os termos universalização e continuidade tenham sido utilizados pelos autores de forma ampla, apenas para indicar o cumprimento de princípios do serviço público. Se a conclusão no capítulo anterior, independente do regime, fosse a de que os serviços de telecomunicações são públicos, nessa hipótese, de fato, a massificação se enquadraria como um princípio dos serviços públicos. ${ }^{36}$ A partir dessa premissa, seria mais compreensível a proposta dos autores de que, no regime privado, se observassem os princípios de universalização e continuidade. Contudo, a proposta apresentada foi distinta: propôs-se que apenas no regime público os serviços são públicos.

Dito isso, é preciso avançar no entendimento de como efetivar a massificação no regime privado, sem relacioná-los aos princípios do serviço público.

$\mathrm{O}$ art. 128 da LGT prescreve que a Agência deve observar a exigência de mínima intervenção na vida privada. Todavia, esse mesmo artigo admite a imposição de condicionamentos administrativos ao direito de exploração das diversas modalidades de serviço no regime privado. Na mesma linha, a LGT possibilita, em seu art. 135, o estabelecimento de condicionantes de compromissos de interesse da coletividade às autorizações, muito embora essas outorgas estejam no âmbito da iniciativa privada. ${ }^{37}$

Também há permissão legal, no art. 71 da LGT, para que a Agência estabeleça restrições, limites ou condições à obtenção e transferência de concessões, permissões e autorizações, tudo visando promover a competição efetiva, bem como impedir a concentração econômica no mercado.

Em síntese,

${ }^{36}$ Note que, se o princípio da continuidade fosse aplicado no regime privado, sem maiores aprofundamentos, poder-se-ia, chegar a interpretação de que a União deveria garantir a continuidade, caso as empresas iniciassem atividade de telecomunicações e, que por qualquer motivo, desejassem encerrá-la. Isso incluiria, além das empresas de telefonia celular, de televisão por assinatura, radiotaxi e etc.

${ }^{37}$ Lembre-se que os serviços de interesse coletivo, tanto no regime público como no regime privado, sujeitam-se a condicionamentos para que sua exploração atenda 0 interesse da coletividade (Art.17, parágrafo único, Resolução nº 73/1997, da Anatel) 
"permite-se à Anatel o estabelecimento de limitações ou a imposição de encargos que não seriam normais em um regime de mercado. Mas isso tem caráter excepcional e deve observar a existência de vínculos de necessidade e adequação com certas finalidades devidamente especificadas, assim como gerar um proveito proporcional à privação imposta (cf.128 e incisos da LGT).” (FARACO, 2003, p. 129)

Segue-se a linha de que esses condicionantes existem em razão do poder de polícia que a União possui sobre os serviços prestados sob a autorização. Alexandre de Aragão define limitações administrativas como qualquer condicionamento ou redução ao exercício de liberdades e propriedades, “operada pela Administração Pública com base em lei ou na Constituição, ponderando-as com outros valores constitucionais, mas sem atingir o núcleo essencial de tais liberdades e propriedades." (ARAGÃO, 2012, p. 177)

Adverte o autor que, ao editar essas limitações, o Estado tem obrigações tanto comissivas quanto omissivas. Explica-se: no primeiro caso, o Estado deve "fazer o particular respeitar os outros direitos e valores sociais que possam ser afetados pelo exercício indiscriminado da sua liberdade (obrigação de limitar)" (ARAGÃO, 2012, p. 178). Por outro lado, o Estado deve omitir-se porque tem obrigação de respeitar o núcleo essencial de cada liberdade a ser limitada, sob a pena de desconfigurá-la.

É nesse ambiente de poder de polícia do regime privado das telecomunicações que a LGT possibilitou, em algumas situações de interesse social, a limitação do direito da livre iniciativa. A ANATEL, ao estabelecer compromissos, deve fazê-lo por meio de regulamentação, respeitando os princípios da razoabilidade, proporcionalidade e igualdade.

Acredita-se que, com o fim de massificar, seja possível a imposição de limitações administrativas às autorizações com o fim de concretizar os princípios regulatórios sociais: (i) redução das desigualdades regionais e (ii) ofertas, o mais homogêneas possível, em todo território nacional, sem que, com isso, o núcleo essencial da livre iniciativa seja extinto.

\section{Mecanismos de Massificação: Exemplos}

Diferentemente do que ocorre na universalização que, no âmbito do regime público, possui mecanismos próprios de expansão do serviço, a massificação dos serviços em regime privado não possui mecanismos definidos, de modo que o condicionamento permitido em lei é o instrumento para, pontualmente, estimular a ampliação de serviços. Nesse sentido, são apresentados dois exemplos, considerando a preocupação atual em massificar os serviços de banda larga fixa (SCM) e telefonia celular (SMP).

O primeiro exemplo é mais amplo do que o escopo da ANATEL. Tratase de política pública de Governo que prioriza a massificação da Banda Larga, 
por meio do Programa Nacional de Banda Larga e do Programa Brasil Conectado (PNBL). Para tanto, desenvolveu-se um conjunto de ações, nas quais se exige também a atuação da ANATEL.

Além disso, seguindo a Portaria $\mathrm{n}^{\circ}$ 178, de 22 de abril de 2008, do Ministério das Comunicações e o PGR elaborado pela ANATEL tem-se atuado para ampliar o acesso à telefonia móvel. É sob esse contexto que se apresenta o segundo exemplo.

\section{Plano Nacional de Banda Larga}

O PNBL, oficialmente instituído pelo Decreto $\mathrm{n}^{\circ} 7.175$, de 12 de maio de 2010, visa fomentar o uso e o fornecimento de bens e serviços de tecnologias de informação e comunicação, de modo a: massificar o acesso a serviços de conexão à Internet em banda larga; acelerar o desenvolvimento econômico e social; promover a inclusão digital; reduzir as desigualdades social e regional; promover a geração de emprego; ampliar os serviços de Governo Eletrônico e facilitar o uso dos serviços do Estado; promover a capacitação para o uso das tecnologias de informação; e, aumentar a autonomia tecnológica e a competitividade brasileiras.

Em síntese, o PNBL é uma política pública que tem a intenção de estimular a expansão da infraestrutura dos serviços de telecomunicações, nas quais as atividades da ANATEL se inserem. Além disso, possibilitar melhores condições de preço, cobertura e qualidade. "A meta é proporcionar o acesso à banda larga a 40 milhões de domicílios brasileiros até 2014 à velocidade de no mínimo 1 Mbps" (estabelece o Plano). Para tanto, diversas ações são determinadas pelo citado Decreto ou pensadas ${ }^{38}$ a partir de suas diretrizes, das quais se destacam algumas.

A primeira dessas diretrizes é a ampliação da rede nacional. O Decreto determinou a reativação da sociedade de economia mista Telebras, para, entre outras atribuições, ser o suporte nas políticas públicas de banda larga. ${ }^{39}$

Nesse sentido, concretamente, a Telebras está expandindo uma rede e oferecendo serviços de acesso dedicado à internet aos prestadores de serviços de telecomunicações, desde que eles possuam autorização expedida pela ANATEL e que sejam ofertados aos usuários finais a preços módicos.

Além disso, a Telebras auxilia na implantação do projeto cidades digitais $^{40}$ do Ministério das Comunicações. Apenas, excepcionalmente, a

${ }^{38} \mathrm{O}$ Decreto determinou a criação do Fórum Brasil Conectado para a promoção do diálogo e definições de metas a serem implementadas.

${ }^{39}$ Para entender a reativação da Telebras, ver SIQUEIRA (2010, p. 22-25).

${ }^{40}$ Para entender o contexto inicial do projeto, ver PAIVA et al. (2007, p. 26-30). 
Telebras oferta serviço ao usuário final, sendo a sua vocação ofertar no atacado e estimular o desenvolvimento de pequenas empresas.

A segunda diretriz é promover incentivos fiscais e financeiros. Assim, com Regime Especial de Tributação do Programa Nacional de Banda Larga (REPNBL) tem-se a desoneração tributária para estímulo ao investimento em redes. Há redução das alíquotas de PIS/Cofins para projetos de implantação, ampliação ou modernização de redes de telecomunicações que suportam acesso à internet banda larga e para terminais de acesso. O Ministério das Comunicações acredita que, dessa forma, há incentivo à universalização ${ }^{41} \mathrm{da}$ banda larga porque assim o preço final é reduzido.

A terceira diretriz refere-se às ações regulatórias. Para tanto, o Ministério indicou políticas públicas prioritárias à ANATEL. Desde 2010, a ANATEL editou alguns regulamentos que auxiliaram direta ou indiretamente o PNBL, entres outros, destacam-se a Resolução no 574, de 28 de outubro de 2011, que aprovou o Regulamento de Gestão da Qualidade do Serviço de Comunicação Multimídia (RGQ - SCM); a Resolução nº 600, de 8 de novembro de 2012, que aprovou o Plano Geral de Metas de Competição (PGMC); licitações de faixa de radiofrequência que permitiram o uso de tecnologias que ofertam banda larga móvel; e, a Resolução $n^{\circ}$ 614, de 28 de maio de 2013, que aprovou o novo Regulamento do Serviço de Comunicação Multimídia.

Sobre o novo Regulamento do Serviço de Comunicação Multimídia (SCM), destaca-se o objetivo de criar assimetrias regulatórias baseadas no conceito de prestador de pequeno porte, cuja presença estimula competir e ocupar segmentos de mercados vazios ou mal explorados. Reduziu-se o preço pago pela outorga do serviço de $\mathrm{R} \$ 9.000,00$ para $\mathrm{R} \$ 400,00$ quando a área de prestação for regional e não em todo o território nacional. Nesse contexto de massificação, o Conselheiro Relator Marcelo Bechara, afirmou em sua Análise $\mathrm{n}^{\mathrm{o}} 304$, de 17 de maio de 2013:

5.9. Portanto, é salutar que os serviços de telecomunicações, cujas redes servem de suporte ao acesso à banda larga, sejam altamente inclusivos do ponto de vista social de modo, também, a se alinharem às políticas estabelecidas pelo Poder Executivo, materializadas, em grande parte, no PNBL.

5.10. Assim, por se tratar de serviço abrangente e dotado de inúmeras aplicações, sendo um deles o suporte à comunicação em Banda Larga, o SCM apresenta-se como um dos instrumentos de democratização do acesso às

${ }^{41}$ Esse é o termo encontrado no site do Ministério das Comunicações: MINISTÉRIO DAS COMUNICAÇÕES. Programa nacional de banda larga (PNBL). Brasília, 2013. Disponível em: <http://www.mc.gov.br/acoes-e-programas/programa-nacional-de-bandalarga-pnbl>. Acesso em: 26 de março de 2013. 
tecnologias de informação, de redução das desigualdades nesse acesso e de garantia de direitos como educação, saúde, informação e comunicação.

É bem verdade que as ações citadas ramificam-se em outras, contudo, não é objeto desse trabalho dissecar o PNBL ou emitir juízo de valor acerca dele. ${ }^{42}$ Menciona-se o PNBL para exemplificar uma medida de massificação incidente sobre a banda larga, em que estão presentes: financiamento estatal e ações regulatórias com objetivo de expandir a rede; e, como consequência dessa política, provimento do acesso à internet a preços módicos.

\section{Licitações no Regime Privado}

No plano de atuação da ANATEL, a principal medida de massificação do SMP tem ocorrido por meio das licitações de radiofrequência.

Antes, pois, de adentrar no exemplo, é preciso abordar questões jurídicas de fundo. Embora a regra seja a de que os serviços autorizados não tenham um número limitado de outorgas (art. 136, caput, da LGT), a própria LGT abre a possibilidade de condicionantes. A partir dos parágrafos do art. 136 da LGT, identificam-se dois casos de limitação.

O primeiro é de transferência de outorga, que pode não ser aprovada, caso a ANATEL entenda que a medida prejudica a competição ou a execução do contrato. A segunda hipótese ocorre quando há necessidade de associar a prestação do serviço a uma banda de radiofrequências. Nesse caso, a livre iniciativa depende de acesso ao espectro de radiofrequências que é um bem público escasso e limitado. Quando as faixas são limitadas e o uso por um exclui o uso simultâneo de outros, a licitação passa a ser imperativa e, portanto, excepcionalmente limitadora do número de outorgas.

Havendo licitação, ela será sempre onerosa e deverá ocorrer nos termos dos arts. 89 e 164, I da LGT. A licitação possui um caráter instrumental; ela representa o início de um procedimento de implantação da regulação como um meio para atingir uma finalidade pública maior. Isso porque ela não é um fim em si mesmo. O procedimento licitatório é também uma forma de "regulação diretiva ou indutiva da economia, seja para coibir práticas que limitem a competitividade, seja para induzir práticas que produzam efeitos sociais desejáveis.” (FERRAZ, 2009, p. 133-142)

$\mathrm{O}$ art. 135 da LGT permite, excepcionalmente, em face de relevantes razões de caráter coletivo, a possibilidade de condicionar a expedição de autorização à aceitação, pelo interessado, de compromissos de interesse da

${ }^{42}$ Com intuito de identificar críticas jurídicas ao modelo de estímulo à banda larga que vem sendo desenvolvido, recomenda-se a leitura de Marques Neto (2010, 53-61); e, Araújo (2012, 24-35) para entender o PNBL e perspectivas atuais. 
coletividade. Esses compromissos ${ }^{43}$ deverão ser regulamentados, devendo ser observados os princípios da razoabilidade, proporcionalidade e igualdade. Nesse contexto, entende-se possível que se estabeleçam compromissos de interesse da coletividade, conforme determinado no art. 135 da LGT, nas licitações de outorga de serviço.

Marcos Juruena Villela Souto, um dos propulsores na defesa da função regulatória da licitação, alerta que a "discricionariedade na formação do edital envolve o exercício de uma competência regulatória, pois interfere na estrutura do mercado (...)" (SOUTO, 2005, p. 308). O autor alerta que o objetivo da licitação não necessariamente se limita ao menor preço, "a melhor proposta pode ser aquela que faz ressurgir um mercado livre. Do contrário, não há licitação séria, porque não há livre competição num mercado dominado ou inexistente." (SOUTO, 2003, p. 40-47)

Esclarecidas as possibilidades de outorgar serviços privados por licitação e de o edital, como instrumento regulatório, conter condicionantes de relevante interesse social, analisa-se a massificação do serviço móvel.

Desde 2007, a ANATEL inseriu os chamados "compromissos de abrangência" nos editais de licitação de algumas autorizações de radiofrequência do Serviço Móvel Pessoal (SMP). A primeira vez foi no Edital 001/2007. Contudo, essa prática ganhou notoriedade no Edital 002/2007, em que se licitou a outorga de autorização de uso de radiofrequências de quatro bandas da frequência de $3,5 \mathrm{GHz}$.

O objetivo da licitação foi garantir que todo o território nacional tivesse acesso ao serviço móvel e que a tecnologia $3 \mathrm{G}$ fosse comercializada em todo o País e não só nas regiões economicamente mais desenvolvidas. Dessa forma, dividiu-se o Brasil em 11 áreas. Para impedir que as menos interessantes não recebessem proposta, determinou-se, por exemplo, que a empresa vencedora da cidade de São Paulo (área III) necessariamente levaria parte da Região Norte (área VIII).

Além disso, foram estabelecidos os compromissos de abrangência, entre os quais se destaca o dever de cobrir todos os municípios que não tinham cobertura móvel, independente da tecnologia, em 24 (vinte e quatro) meses a contar da assinatura dos contratos e sua publicação no DOU. Outra obrigação foi que, em todos os municípios com mais de 100.000 (cem mil habitantes), a

\footnotetext{
${ }^{43}$ Segundo MARQUES NETO et al. (2011, p. 65), cabe a ressalva, "O tema é certamente passível de amplo debate, já que, dependendo do nível de compromissos que venha a impor, haverá desnaturação do regime privado de prestação de telecomunicações, na medida em que esses compromissos tenderão a se aproximar ou de obrigações de universalização ou de continuidade. Não bastasse isso, esses compromissos podem ter fortíssimo impacto no plano da competição (...).”
} 
tecnologia 3G deveria estar disponível em até 60 (sessenta) meses a contar da assinatura dos contratos e sua publicação.

Licitações desse tipo são classificadas como concorrência melhor técnica e preço. O plano de negócios, que estabelece o preço mínimo de cada um dos lotes da licitação, considera as obrigações que a vencedora deverá cumprir. Dessa forma, o preço mínimo cai e considera-se que a diferença monetária entre o que deveria ser o preço mínimo real e o efetivamente estabelecido será reinvestido no próprio mercado de telecomunicações por meio do cumprimento das obrigações. Esta lógica tem possibilitado que, mesmo com obrigações subsidiárias, as licitações sejam bem sucedidas.

Não resta dúvida de que os compromissos de abrangência interferem no mercado, uma vez que condicionam a autorização e obrigam que as vencedoras cumpram metas que, talvez, não fossem economicamente interessantes. Por outro lado, justamente para estimular o mercado, na licitação, há um deságio. Calcula-se o quanto valeria a faixa de radiofrequência, e desse valor é subtraído o valor estimado para cumprimento das obrigações que serão imputadas às vencedoras. Em outros termos, há um financiamento indireto para o cumprimento das obrigações.

Essas obrigações nada mais são do que meios de estimular investimentos em infraestruturas com o intuito de promover o acesso (massificar), sem que, contudo, haja cobrança de serviço por tarifas, obrigações de continuidade do serviço ou bens reversíveis. Isso porque, tanto o uso de radiofrequência quanto o serviço são outorgados mediante autorizações, amparadas pelo regime privado.

\section{Universalização e Massificação}

Como verificado, a definição de massificação das telecomunicações não se encontra acostada em nenhuma norma legal. Contudo, é cada vez mais frequente que os termos massificação e universalização apareçam juntos, ${ }^{44}$ podendo gerar duas expectativas: a de que têm conteúdo distinto ou a de que são sinônimos. Isso porque, em síntese, a palavra universalização remete ao conjunto de obrigações do regime público e às características de serviço público, enquanto a massificação é o termo empregado para definir expansão do acesso às telecomunicações no regime privado. Em verdade, são utilizadas em regimes

${ }^{44}$ Entre outros: (a) MINISTÉRIO DAS COMUNICAÇÕES. Universalização e massificação dos serviços de telecomunicações". Brasília, 2013. Disponível em: $<$ http://www.mc.gov.br/acoes-e-programas/universalizacao-e-massificacao-dos-servicos-de-telecomunicacoes〉. (b) MARIA FRÔ, João Brant: fust, PNBL - universalizar não é massificar. Disponível em: 〈http://mariafro.com/2011/04/13/joao-brant-Fust-pnbl-universalizar-nao-e-massificar/>. Acesso em: 25 mar. 2013. 
jurídicos distintos para atingir o mesmo fim, porém, com procedimentos diferentes.

Frise-se que ambos buscam como vetor o acesso, contudo, os regimes estabelecem pilares e embasamento jurídico distinto. Enquanto a massificação busca estimular a disponibilização do acesso por meio de regulamentação, condicionamentos e limitações, a universalização do regime público preocupa-se em permitir o mínimo e o básico de comunicação. Nesse último caso, a União se compromete em garantir a continuidade desse mínimo.

Fato é que "a autorização constitui um dos instrumentos mediante os quais a Administração Pública intervém sobre a atividade econômica privada" (FARIAS, 2005, p. 117). Isso se verifica de distintas formas para os variados serviços, não apenas nos casos de licitação, mas também quando se estabelecem parâmetros de qualidade do serviço, quando se exige que os planos/pacotes de serviços só sejam homologados, quando se exige o fornecimento de dados, entre outras.

É ingênuo acreditar ou defender que, no regime privado, não há interferência do Estado, mesmo porque, como já exposto, os serviços de telecomunicações são essenciais e a eles são impostos limites administrativos em razão do poder de polícia.

A proposta do legislador foi de que o Estado atuasse de maneira a proteger o consumidor/usuário ao passo que estimulasse a competição e o desenvolvimento de pequenos mercados. Nesse contexto, massificar significa promover, no regime privado, o acesso aos serviços de telecomunicações, expandindo as redes, inclusive, em áreas economicamente menos interessantes, mediante estímulos financeiros adicionais por parte do governo, gerando, consequentemente, diminuição nas desigualdades regionais, crescimento do setor e benefícios a todos os usuários. Repita-se, não há que se falar em serviços de titularidade do governo e sim no âmbito das atividades privadas regulamentadas. Medidas de massificação visam concretizar os seguintes princípios regulatórios: acelerar a redução das desigualdades regionais e possibilitar oferta de serviços de forma mais homogênea possível em todo território nacional.

A LGT ao definir obrigações ao regime público que, a partir de características próprias, tornam os serviços prestados nesse regime de natureza pública. Por outro lado, admitir a existência de princípios sociais que, em algumas circunstâncias, geram limitações ao regime privado não significa dizer que os serviços prestados nesse regime sejam automaticamente obrigados às regras de universalização do regime público (que possuem mecanismos próprios e rígidos) ou que eles passem a ser serviços públicos. Ao contrário, lembrando os ensinamentos de Gastón Jèze, não há um critério único para a definição de serviços públicos e sim um conjunto de circunstâncias que, isoladamente, não 
indicariam per si sua existência (JÈZE, 1949, p. 291-293). No caso, o objetivo de massificar seria incapaz de transformar os serviços privados em serviços públicos.

Assim, considerando os parâmetros gerais de universalização já estudados e considerando o conceito que ora se adota de massificação, massificar é universalizar. ${ }^{45}$ Contudo, como o termo universalização em telecomunicações é bem delimitado e possui características distintas da massificação, que se verifica apenas quando da necessidade de regulamentação que estimule ou, em alguns casos, limite a atuação da iniciativa privada, concluise ser adequada a utilização de termos distintos.

\section{Conclusão}

O primeiro objetivo do trabalho foi verificar se as três possibilidades de outorgas de serviço de telecomunicações (concessão, permissão e autorização) deveriam ser classificadas como serviços públicos. Identificou-se que os serviços de telecomunicações, prestados sob o regime público, sejam classificados como serviços públicos. Por outra parte, a doutrina se divide acerca da categorização dos serviços prestados mediante autorização no regime privado. Após análise das características dos serviços públicos e ampla discussão sobre a titularidade da outorga da autorização, concluiu-se que os serviços prestados em regime privado não são serviços públicos, e sim atividades da iniciativa privada sujeitas ao poder de polícia. Delimitou-se, então, a principal diferença entre os regimes público e privado estabelecidas na LGT.

Na sequência, analisou-se uma possível semelhança. Para tanto, discutiuse a ampliação do acesso aos serviços de telecomunicações e como é tratada nos diferentes regimes. No regime público, utiliza-se o termo universalização, que encontra definição e parâmetros estabelecidos na LGT, enquanto que, no regime privado, emprega-se o vocábulo massificação, embora não esteja definido em nenhuma norma, cada vez mais utilizado no setor.

Com a intenção de ampliar o acesso e impulsionar o desenvolvimento de infraestrutura de telecomunicações no País, a ANATEL tem estabelecido obrigações tanto para as concessionárias quanto para as autorizadas. Nesse sentido, acredita-se haver semelhanças entre os regimes público e privado, muito embora verifiquem-se justificativas jurídicas distintas para embasar a universalização e massificação, respectivamente.

${ }^{45}$ Lembre-se da proposta de definição e entendimento da UIT sobre serviço universal. Parece ser também esse o entendimento de Aragão (2005, 46): “(...) são justamente os serviços que foram despublicizados (telefonia celular) - e não os serviços públicos - que, na prática, estão propiciando a universalização das telecomunicações no Brasil.” 
A partir do entendimento de diferença e semelhança entre os regimes, acredita-se que proposta de políticas públicas e regulamentações podem ser mais bem fundamentadas.

\section{Referências Bibliográficas}

AGUILlAR, Fernando Herren. Serviços Públicos: doutrina, jurisprudência e legislação. São Paulo: Saraiva, 2011.

ARAGÃO, Alexandre Santos de. Atividades privadas regulamentadas: autorização administrativa, poder de polícia e regulação. Revista de direito público da economia. Belo Horizonte, v. 3, n. 10, p. 9-48, abr./jun. 2005.

. Direitos dos serviços públicos. Rio de Janeiro: Forense, 2007.

. Curso de direito administrativo. Rio de Janeiro: Forense, 2012.

ARAÚJO, Paulo Sisnando Rodrigues de. Considerações sobre o programa nacional de banda larga. Revista do TCU, Brasília, ano 44, n. 124, p. 24-35, maio/ago. 2012.

BATISTA, Joana Paula. Remuneração dos serviços públicos. São Paulo: Malheiros, 2005.

BIELSCHOWSKY, Ricardo (comp.). Sesenta años de la CEPAL. textos seleccionados del decenio 1998-2008. Bueno Aires: Siglo Veintiuno Editores, 2010.

BRASIL. Ministério da Administração Federal e da Reforma do Estado (MARE). Plano Diretor de Reforma do Aparelho do Estado. Brasília, 1995.

BRASIL. Ministério das Comunicações. Exposição de Motivos nº 231/1996.

CAETANO, Marcello. Princípios fundamentais do direito administrativo. Coimbra: Almedina, 1996.

CARDOSO, Fernando Henrique. Mãos à obra, Brasil: proposta de governo. Centro Edelstein de Pesquisas Sociais. Rio de Janeiro, 2008.

CARVALHO FILHO, José dos Santos. Manual de direito administrativo. $26^{\text {a }}$ ed., São Paulo: Atlas, 2013.

CASSAGNE, Juan Carlos. La intervención administrativa. $2^{\text {a }}$ ed., Buenos Aires: Abeledo-Perrot, 1994.

CAVALCANTI, Themistocles Brandão. Curso de direito administrativo. $8^{\mathrm{a}}$ ed., Rio de Janeiro: Freitas Bastos, 1967.

COSCIONE, Milene Louise Renée. Telecomunicações: doutrina, jurisprudência, legislação e regulação setorial. São Paulo: Saraiva, 2011. 
COSTA, Carlos J. da. Telecomunicações: Passaporte para a modernidade. Rio de Janeiro: Instituto Liberal, 1996.

CRETELLA Jr, José. Administração indireta brasileira. Rio de Janeiro: Forense, 1980.

D’ALBUQUERQUE, Daniel Martins. As agências reguladoras e a formulação de políticas públicas: uma abordagem a partir da universalização das telecomunicações por meio do Fust. Brasília: UniCeub, 2013.

DERANI, Cristiane. Privatização e serviços públicos: as ações do estado na produção econômica. São Paulo: Max Limonad, 2002.

DI PIETRO, Maria Sylvia Zanella. Parcerias na administração pública: concessão, permissão, franquia, terceirização, parceria público-privada e outras formas. $8^{a}$ ed., São Paulo: Atlas, 2011.

. Maria Sylvia Zanella. Direito administrativo. 25ª ed., São Paulo: Atlas, 2012.

DROMI, Roberto. Derecho administrativo. $5^{\text {a }}$ ed., Buenos Aires: Ciudad Argentina, 1996.

DUGUIT, Leon. Manual de derecho constitucional. Granada: Comares, 2005.

ESCOBAR, J. C. Mariense. Serviços de telecomunicações: aspectos jurídicos e regulatórios. Porto Alegre: Livraria do Advogado, 2005.

ESTORNINHO, Maria João. A fuga para o direito privado. Coimbra: Livraria Almedina, 1996.

FARACO, Alexandre Ditzel. Regulação e direito concorrencial - as telecomunicações. São Paulo: Livraria Paulista, 2003.

FARACO, Alexandre Ditzel; PEREIRA NETO, Caio Mário da Silva; COUTINHO, Diogo Rosenthal. Universalização das telecomunicações: uma tarefa inacabada. Revista de Direito Público da Economia. Belo Horizonte, v. 1, n. 2, p. 9-58, abr./jun. 2003.

FARIAS, Sara Jane Leite de. Regulação jurídica dos serviços autorizados. Rio de Janeiro: Lumen Juris, 2005.

FERRAZ, Luciano. Função regulatória da licitação. A\&C R. de Dir. Administrativo \& Constitucional. Belo Horizonte, ano 9, n. 37, p. 133-142, jul./set. 2009.

FIUZA, Eduardo Pedral Sampaio; NERI, Marcelo Cortes. Texto para discussão nº 573: reflexões sobre os mecanismos de universalização do acesso disponíveis para o setor de telecomunicações no Brasil. Rio de Janeiro: IPEA, 1998. 
GROTTI, Dinorá Adelaide Musetti. Teoria dos serviços públicos e sua transformação. In: SUNDFELD, Carlos Ari (coord.). Direito administrativo econômico. São Paulo: Malheiros, 2006.

HORBACH, Carlos Bastide. Os princípios do serviço público na França e no Brasil. In: de et al (coord.). Direito público em evolução: estudos em homenagem à Professora Odete Medauar. Belo Horizonte: Fórum, 2013.

JÈZE, Gaston. Principios generales del derecho administrativo. Madrid: Reus, 1928.

. Princípios generales del derecho administrativo. Buenos Aires: Depalma, 1949. T. 2.

KRELL, Andreas J. Discricionariedade administrativa, conceitos jurídicos indeterminados e controle judicial. Revista ESMAFE - Escola de Magistratura Federal da 5ª Região, Recife, n. 8, p. 177-224, dez. 2004.

LAENDER, Gabriel Boavista. O Regime jurídico das telecomunicações e os serviços de telecomunicação. In: ARANHA, Márcio Iorio. Direito das telecomunicações: estrutura institucional regulatória e infraestrutura das telecomunicações no Brasil. Brasília: GETEL/UnB, 2005.

LIMA, Ruy Cirne. Princípios de direito administrativo. 5a ed., São Paulo: Revista dos Tribunais, 1982.

MACHADO, Hugo de Britto. Remuneração dos serviços públicos. In: TÔRRES, Heleno Taveira (coord.) Serviços públicos e direito tributário. São Paulo: Quartier Latin, 2005.

MALJAR, Daniel Edgardo, apud ARAGÃO, Alexandre Santos de. Direito dos serviços públicos. Rio de Janeiro: Editora Forense, 2007.

MARQUES NETO, Floriano de Azevedo. Regime jurídico dos bens públicos empregados na geração de energia. Revista de Direito Administrativo, Rio de Janeiro, v. 232, p. 333-354, abr./jun. 2003. . As políticas de universalização, legalidade e isonomia: o caso "telefone social". Revista de Direito Público da Economia, Belo Horizonte, v. 4, n. 14, p. 75-115, abr/jun. 2006.

. Entre a legalidade e o "puxadinho": a universalização da banda larga no Brasil. Revista de Direito de Informática e Telecomunicações - RDIT. Belo Horizonte, v. 5, n. 9, p. 53-61 jul./dez. 2010.

MARQUES NETO, Floriano de Azevedo; COSCIONE, Milene Louise Renée. Telecomunicações: doutrina, jurisprudência, legislação e regulação setorial.

São Paulo: Saraiva, 2011. 
MEDAUAR, Odete. Direito administrativo moderno. $11^{\text {a }}$ ed., São Paulo: Revista dos Tribunais, 2007.

MEIRELLES, Hely Lopes. Direito administrativo brasileiro. 29a ed., São Paulo: Malheiros, 2004.

MELLO, Celso Antônio Bandeira de. Natureza e regime jurídico das autarquias. São Paulo: Revista dos Tribunais, 1968.

MENEGALE, J. Guimarães. Direito administrativo e ciência da administração. $3^{\mathrm{a}}$ ed., Rio de Janeiro: Borsoi, 1957.

MONTEIRO, Vera. Concessão. São Paulo: Malheiros, 2010.

MOREIRA NETO, Diogo de Figueiredo. Curso de direito administrativo. $12^{\mathrm{a}}$ ed., Rio de Janeiro: Editora Forense, 2002.

. Direito regulatório. Rio de Janeiro: Renovar, 2003.

MOTTA, Paulo Roberto Ferreira. O 'kit' regulatório das telecomunicações. In: FIGUEIREDO, Marcelo e PONTES FILHO, Valmir (orgs). Estudos de direito público em homenagem a Celso Antônio Bandeira de Mello. São Paulo: Malheiros, 2006, p. 667-688.

ONU. União Internacional das Telecomunicações (UIT). Colloquium $\boldsymbol{n}^{\boldsymbol{0}} \mathbf{2}$ - universal service and innovation: fostering linked goals through regulatory policy. Geneva, December 1-3, 1993.

. Elements and principles of the information society." 1998.

PAIVA, Fernando; POSSETI, Helton. Oásis digital: Governo federal prepara plano nacional de digitalização de cidades, inspirado em iniciativas municipais de sucesso. Teletime, São Paulo, Ano 10, nº 101, p. 26-30, jul. 2007.

PARADA, J. Rámon. El sistema garantizador del derecho de defensa de la competencia. In: OSÓRIO, Fabio Medina e SOUTO, Marcos Juruena Villela (coord.) Direito Administrativo: Estudos em homenagem a Diogo de Figueiredo Moreira Neto. Rio de Janeiro: Lumen Juris, 2006.

ROCHA, Fernando Antônio Dusi e LEÃO, Eliana Goulart. Concessões e permissões no século XXI. Brasília: Brasília Jurídica, 1999.

ROLLAND, Louis. Précis de droit administratif. 9ª ed., Paris: Dalloz, 1947.

ROMANO, Santi. Corso di diritto ammnistrativo. $3^{\text {a }}$ ed., Padova: CEDAM, 1937.

SARDENBERG, Ronaldo Mota. Vinte anos da Constituição de 1988: as telecomunicações e o cidadão. In: DANTAS, Bruno (org.). Constituição de 
1988: o Brasil 20 anos depois - Os cidadãos na carta cidadã. Brasília: Senado Federal, Instituto Legislativo Brasileiro, v. 5, p 386-401, 2008.

SILVA, Almiro do Couto e. Os indivíduos e o Estado na realização de tarefas públicas. Revista da Procuradoria-Geral do Estado [do Rio Grande do Sul]. Porto Alegre v. 27, n. 57: p. 181-208, 2003.

SIQUEIRA, André. Uma nova Telebrás: em meio a críticas do setor privado, o governo decide usar a estatal para ampliar o acesso à internet e a concorrência na oferta de banda larga. Carta Capital, São Paulo, v. 15, nº 595, p. 22-25, maio 2010.

SIQUEIRA, Ethevaldo. Telecomunicações Privatização ou Caos. São Paulo: Telepress, 1993.

SOUTO, Marcos Juruena Villela Souto. Contratos administrativos no Brasil: parte I. L \& C : revista de direito e administração pública. Brasília, v. 6, nº 63, p. 4047 , set. de 2003 .

. Direito administrativo regulatório. 2ª ed., Rio de Janeiro: Lumen Juris, 2005.

SUNDFELD, Carlos Ari, Regime jurídico do setor petrolífero. In: SUNDFELD, Carlos Ari (coord.), Direito administrativo econômico. São Paulo: Malheiros, 2006. p. 385-396.

- A regulação de preços e tarifas dos serviços de telecomunicações. In: SUNDFELD, Carlos Ari (coord.). Direito administrativo econômico. São Paulo: Malheiros, 2006. p. 317-328.

XAVIER, Helena de Araújo Lopes. $O$ regime especial da concorrência no direito das telecomunicações. Rio de Janeiro: Forense, 2003.

WALD, Arnoldo; MORAES, Luiza Rangel de; WALD, Alexandre de M. O direito de parceria e a nova Lei de concessões. $2^{a}$ ed., São Paulo: Revista dos Tribunais, 2004, p. 174-178. 